\title{
Environmental Geologic Studies of the Kaiparowits Coal-Basin Area, Utah
}

\section{U.S. GEOLOGICAL SURVEY BULLETIN 1601}





\section{Environmental Geologic Studies of the Kaiparowits Coal-Basin Area, Utah}

\section{By K. A. Sargent}

The Kaiparowits coal basin is a major coal resource area. Geologic and hydrologic studies summarized here should be helpful to land-use planners and land developers 


\section{UNITED STATES DEPARTMENT OF THE INTERIOR}

WILLIAM P. CLARK, Secretary

GEOLOGICAL SURVEY

Dallas L. Peck, Director

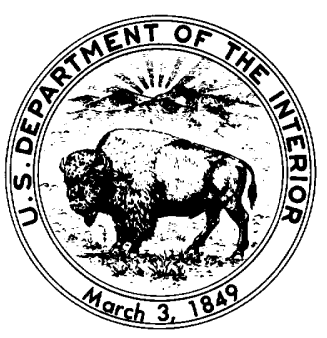

\section{Library of Congress Cataloging in Publication Data}

Sargent, Kenneth A.

Environmental geologic studies of the Kaiparowits coal-basin area, Utah.

(Geological Survey bulletin; 1601)

Bibliography: $30 \mathrm{p}$.

Supt. of Docs. No.: I 19.3:1601

1. Geology-Utah-Kaiparowits Plateau. 2. Hydrology-Utah-Kaiparowits Plateau.

I. Title. II. Series.

QE75.B9 no. 1601

557.3s [333.8'221'0979251]

83-600338 [QE170.K34]

For sale by the Branch of Distribution

U.S. Geological Survey

604 South Pickett Street

Alexandria, VA 22304 


\section{CONTENTS}

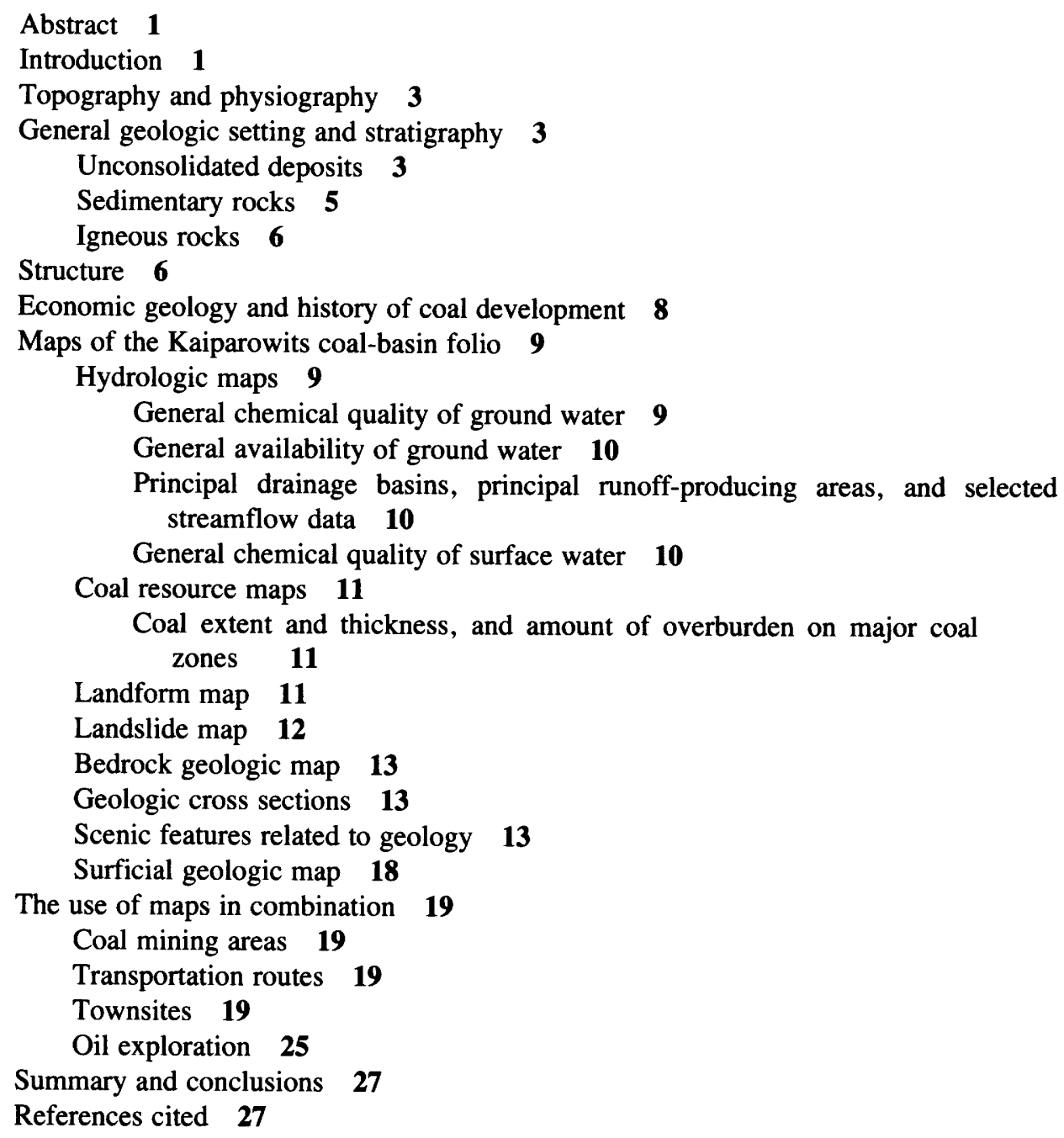


1. Map of Kaiparowits coal-basin area showing generalized geology 2

2. Map of Utah showing physiographic divisions and area of this report 3

3. Map of Kaiparowits coal-basin area showing location of physical and cultural features 4

4. Diagram showing generalized composite stratigraphic section of exposed rocks in the Kaiparowits area 5

5. Map of Kaiparowits coal-basin area showing structural geology features 7

6. Diagram showing relations of members and informal units in the Straight Cliffs Formation-southeast Kaiparowits Plateau coal field 9

7. Sketch showing formation of hogbacks and strike valleys $\mathbf{1 1}$

8. Sketch of stream valley floored with unconsolidated fill which serves as a transportation route to cross from one bench level to another 12

9. Oblique aerial photograph of landslide debris $\mathbf{1 2}$

10-17. Photographs showing:

10. Flash flood on Twentyfive Mile Wash on Hole-in-the-Rock road, September 197713

11. Petrified logs weathering from Petrified Forest Member of the Chinle Formation, northwestern part of Circle Cliffs 13

12. Typical mollusks from Sciponoceras zone, Tropic Shale, south of Escalante 14

13. Cretaceous sharks teeth from Straight Cliffs Formation, southwest of Escalante 15

14. "Moqui marbles" or ironstone concretions from Big Spencer Flats, between Boulder and Escalante 16

15. Sand crystals from Morrison Formation, south of Escalante 17

16. Narrow canyon cut in Navajo Sandstone, Kaibab Gulch $\mathbf{1 8}$

17. Unnamed natural bridge near junction of Alvey Wash and Calf Canyon, southwest of Escalante 18

18-21. Maps showing generalized areas of:

18. Thickest coal 20

19. Thickest coal where overburden is less than $1,000 \mathrm{ft} 21$

20. Thickest coal where overburden is less than $1,000 \mathrm{ft}$ thick, showing areas of roughest terrain $\mathbf{2 2}$

21. Present coal leases and proposed mining sites in relation to thickest coal, least amount of overburden and areas of roughest terrain 23

22. Map of Kaiparowits area showing some existing unimproved roads and the proposed townsite at East Clark Bench 24

23. Map showing all deep drill holes in Kaiparowits Plateau area and showing data on Timpoweap-Kaibab interval 26

24. Map showing exploratory holes in Kaiparowits Plateau area drilled deeper than Timpoweap-Kaibab interval

Inch-Pound-Metric System Equivalents

\begin{tabular}{lll}
\hline \multicolumn{1}{c}{ Inch-pound unit } & Multiplied by & \multicolumn{1}{c}{$\begin{array}{c}\text { To give metric } \\
\text { system equivalent }\end{array}$} \\
\hline Feet (ft) & 0.3048 & Meters (m) \\
Miles (mi) & 1.609 & Kilometers (km) \\
Ton, short (2000 lb) & .9078 & Tons (metric) \\
Btu & .5559 & KCal/kg \\
Gal/min & .06308 & Liters/s \\
\hline
\end{tabular}




\title{
Environmental Geologic Studies of the Kaiparowits Coal-Basin Area, Utah
}

\author{
By K. A. SARGENT
}

\begin{abstract}
The Kaiparowits coal-basin area may contain as much as 20 billion tons of coal; it is a major coal-resource area and a potentially important energy supply area for the southwestern United States. However, the economic development of this coal could constitute a possible threat to the great natural beauty of the area. The impact caused by an attendant increase in population would be great. The U.S. Geological Survey in 1975 started a series of studies of the Kaiparowits coal-basin area. The results of these studies are now being published as a folio consisting of 12 earth-resource maps showing hydrology, bedrock and surficial geology, coal resources, landslides, landforms, and scenic features related to geology. These maps are designed to help landuse planners and land developers make intelligent decisions on the most desirable use of this rich and beautiful land.
\end{abstract}

\section{INTRODUCTION}

The Kaiparowits coal-basin area, one of the most scenic parts of southern Utah, is underlain by as much as 20 billion short tons of coal. Since the late 1960's it has been the focus of controversy between coal developers eager to help satisfy the growing energy demands of southern Arizona and California, and environmentalists anxious to preserve the great beauty of the Canyonlands country. An extensive series of studies of geologic, hydrologic, and topographic factors bearing on coal development in this area was begun in 1975 under the U.S. Geological Survey's Energy Lands Program. This report summarizes the results of this series of studies, which is now (1983) nearing completion. The completed studies are being published as a folio of 12 maps in the U.S. Geological Survey's Miscellaneous Investigations Series, numbered I-1033-A through I-1033-L. These maps provide accurate and objective data designed to aid in the making of intelligent regional land-use decisions. Ten maps have been published since 1977, and the remaining two are in press.
The study area is a $1^{\circ} \times 1^{\circ}$ quadrangle centered on the Kaiparowits Plateau (fig. 1). It lies between lat $37^{\circ}$ and $38^{\circ} \mathrm{N}$. and long $111^{\circ}$ and $112^{\circ} \mathrm{W}$. Bryce Canyon National Park is near its west border, Lake Powell is near the border on the southeast, the Waterpocket Fold and Henry Mountains border on the east, and the Aquarius Plateau borders on the north. Altitude ranges from about $3,700 \mathrm{ft}$ at Lake Powell to $11,000 \mathrm{ft}$ on the Aquarius Plateau. The area extends very slightly into Arizona along the southern boundary.

Ninety percent of the land in the coal-basin area is controlled by the Federal Government and administered through the Bureau of Land Management, Bureau of Indian Affairs, Forest Service, and Park Service. The remainder is either State or privately owned. The area includes parts of Dixie National Forest, Capitol Reef National Park, Glen Canyon National Recreation Area, Navajo Indian Reservation, Paria Primitive Area, and numerous outstanding natural areas.

Many of the data summarized here are refinements of the work of earlier investigators as reported in journals and in publications of the State of Utah and the U.S. Geological Survey. Perhaps best known are the works of H. E. Gregory, who wrote of the geology of the Kaiparowits region (Gregory, 1948; Gregory and Moore, 1931). Much has also been published by the Utah Geological and Mineral Survey (UGMS) on the area; Doelling and Graham (1972) published an important paper on the coal fields of southern Utah. Major regional geologic maps by L. F. Hintze and W. L. Stokes have been printed by the Utah State Land Board (Hintze, 1963; Hintze and Stokes, 1964).

Other work includes efforts by the U.S. Geological Survey: 1:250,000-scale mapping of the Escalante $1^{\circ} \times 2^{\circ}$ quadrangle by Hackman and Wyant (1973); coal investigation maps at 1:24,000 scale by Bowers (1973a, b, c; 1975), Peterson (1973, 1975), Peterson and Barnum (1973a, b, c, d), Stephens (1973), Zeller (1973a, b, c, d; 1978), and Zeller and Stephens (1973).

Also useful for this report were parts of the 1976 Bureau of Land Management Environmental Impact Statement on the proposed Kaiparowits power project and the Department of the Interior's Environmental Statement on development of coal resources in southern Utah (1979). 


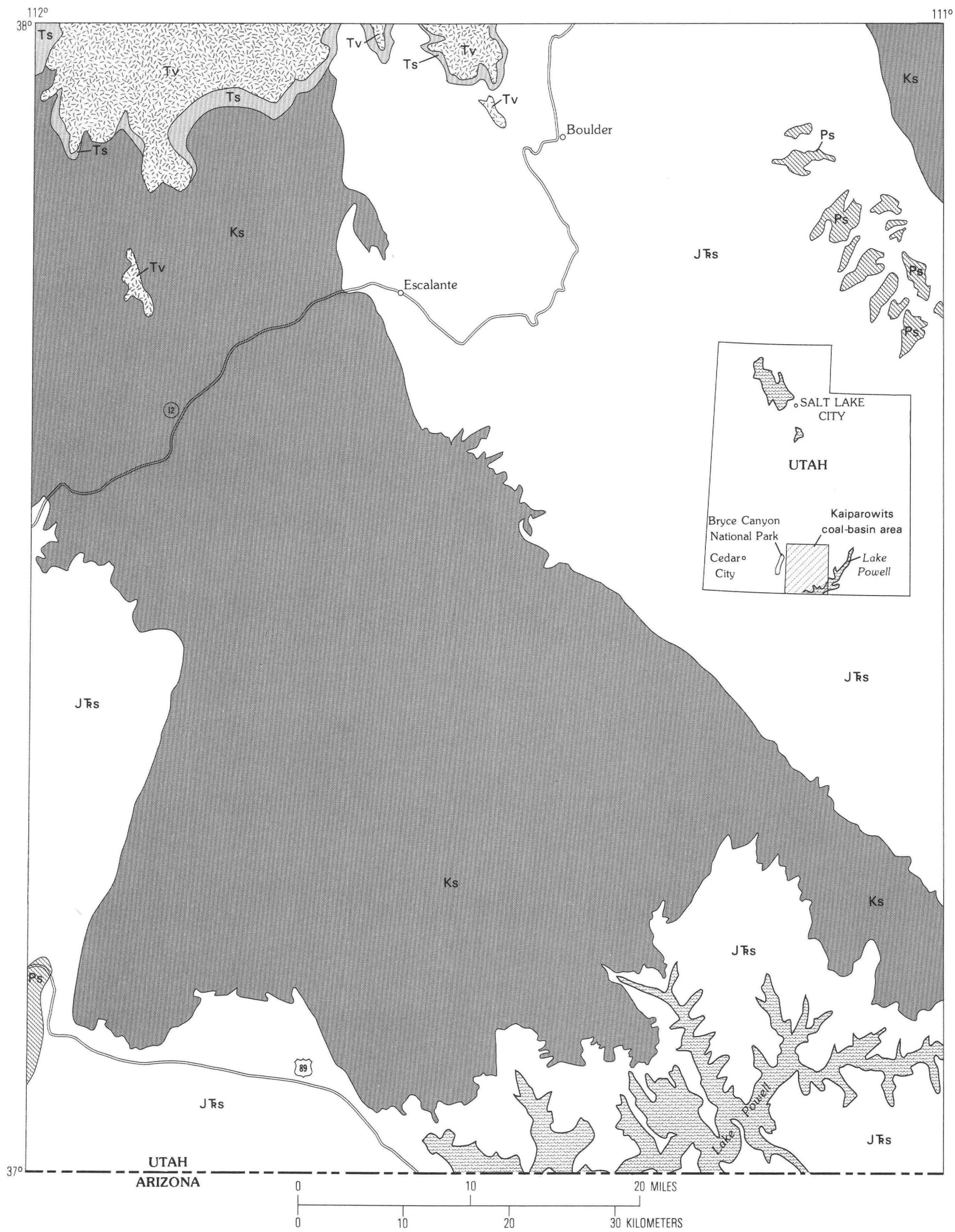

Figure 1. Kaiparowits coal-basin area, showing generalized geology. Inset map shows location of Kaiparowits coalbasin area in Utah. Tv, Tertiary volcanic rocks; Ts, Tertiary sedimentary rocks; Ks, Cretaceous sedimentary rocks, containing coal; JKs, Jurassic and Triassic sedimentary rocks; Ps, Permian sedimentary rocks. 


\section{TOPOGRAPHY AND PHYSIOGRAPHY}

The study area is divided between the Canyon Lands and High Plateaus of Utah (fig. 2). These sections are characterized by terraced plateaus, monoclinal ridges, high mesas, and deep canyons. From the northern part of the area, the plateaus descend southward by a series of large rock terraces or benches that are generally 20-60 mi long and as much as $10 \mathrm{mi}$ wide (Sargent and Hansen, 1980). The cliffs that separate the different terraces range in height from a few hundred to as much as $1,500 \mathrm{ft}$. The terraces are dissected by branching canyons, the longer canyons cutting across successive terraces.

The topographic features of the Kaiparowits coalbasin area are developed on sedimentary strata, except for the volcanic rocks that partly cover the Aquarius Plateau. The rocks of the High F'lateaus and Canyon Lands are generally flat or only slightly tilted; however, along narrow monoclines such as the Waterpocket Fold in the northeastern part and the East Kaibab Fold (The Cockscomb) in the southwestern part of the area, rocks are tilted to as much as $70^{\circ}$.

The northwestern part of the area is drained by the north-flowing East Fork Sevier River (fig. 3); all other streams flow southward to the Colorado River. Of the south-flowing streams, the Escalante River and some of its tributaries are perennial within the plateau area; the rest are intermittent except where springs and seeps provide perennial flow in short, widely separated reaches of the canyons.

The altitudes in the region range from about 3,700 $\mathrm{ft}$ at Lake Powell on the south to $11,000 \mathrm{ft}$ on the Aquarius Plateau (fig. 3) to the north. Changes in altitude are generally abrupt, although gentle rolling topography may be present on terraces and plateaus. Above the valley floors, the terraces, or benches, rise by steps from south to north. Each bench is underlain by an erosion-resistant geologic unit. In the Kaiparowits Plateau area, the benches are well developed. (Physical features are shown on Escalante 1:250,000-scale USGS topographic quadrangle, 1956-62.) The first bench (unnamed) is just above Lake Powell, at about $3,800 \mathrm{ft}$. Successively higher benches occur at 4,200-4,400 ft (Grand Bench, Sit Down Bench), 5,000-5,400 ft (Nipple Bench), 6,000-6,200 ft (Fourmile Bench), and 10,200-11,000 ft (Aquarius Plateau).

\section{GENERAL GEOLOGIC SETTING AND STRATIGRAPHY}

Most of the exposed section in south-central Utah is composed of Mesozoic sedimentary rocks. However, in areas of upwarp and deep erosion, such as at the Circle Cliffs, rocks as old as Permian are exposed. The highest

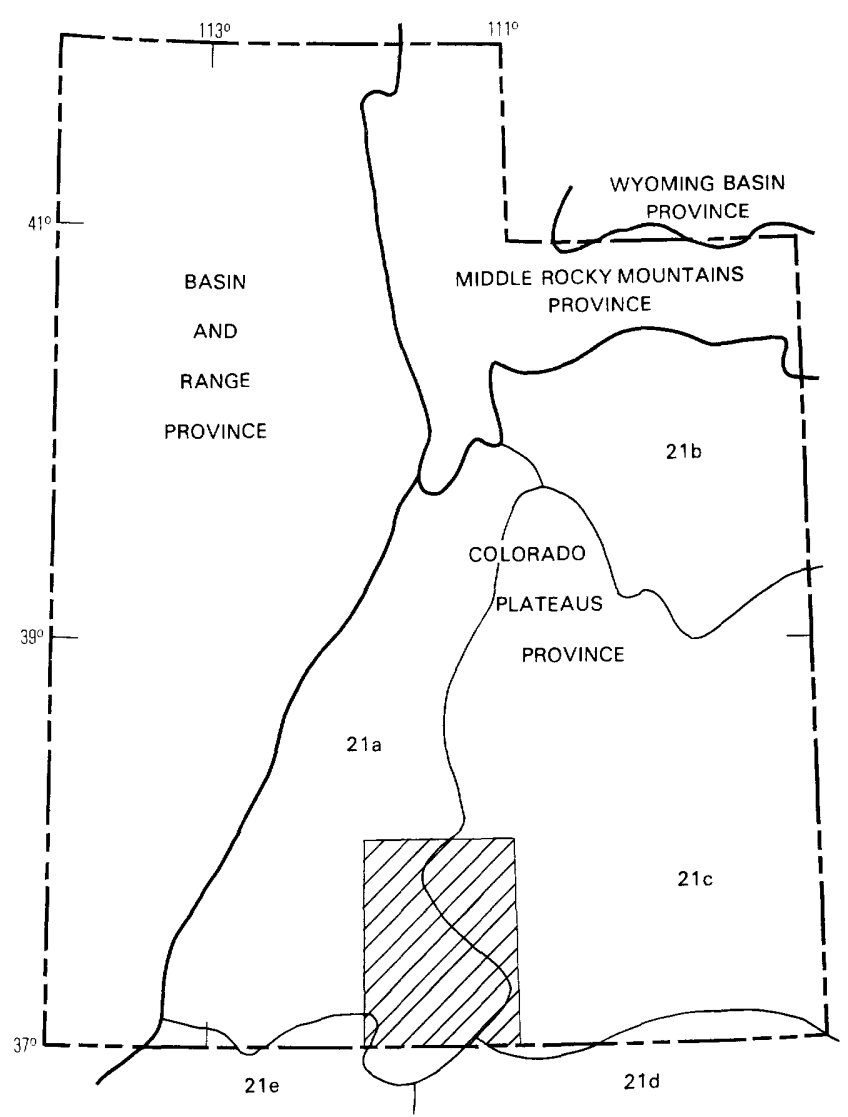

Figure 2. Map of Utah showing physiographic divisions and area of this report (patterned). Divisions of the Colorado Plateaus province are 21a, High Plateaus of Utah; 21b, Uinta Basin; 21c, Canyon Lands; 21d, Navajo section; 21e, Grand Canyon section (modified from Fenneman, 1931).

plateaus are capped with Tertiary and some Quaternary volcanic rocks. Figure 4 is a generalized composite stratigraphic section that shows most of the units generally recognized in south-central Utah. A generally thin cover of Quaternary unconsolidated deposits is common throughout the area; locally these deposits may be as much as several hundred feet thick. These deposits are not shown on figure 4 .

\section{Unconsolidated Deposits}

Unconsolidated deposits are largely Quaternary alluvium, colluvium, and gravel. Windblown sand and silt are common, especially in the south half of the area. Landslide deposits are common on steep slopes, especially those underlain by thick shales or poorly consolidated siltstones on the flanks of the Aquarius Plateau or around Fiftymile Mountain. 


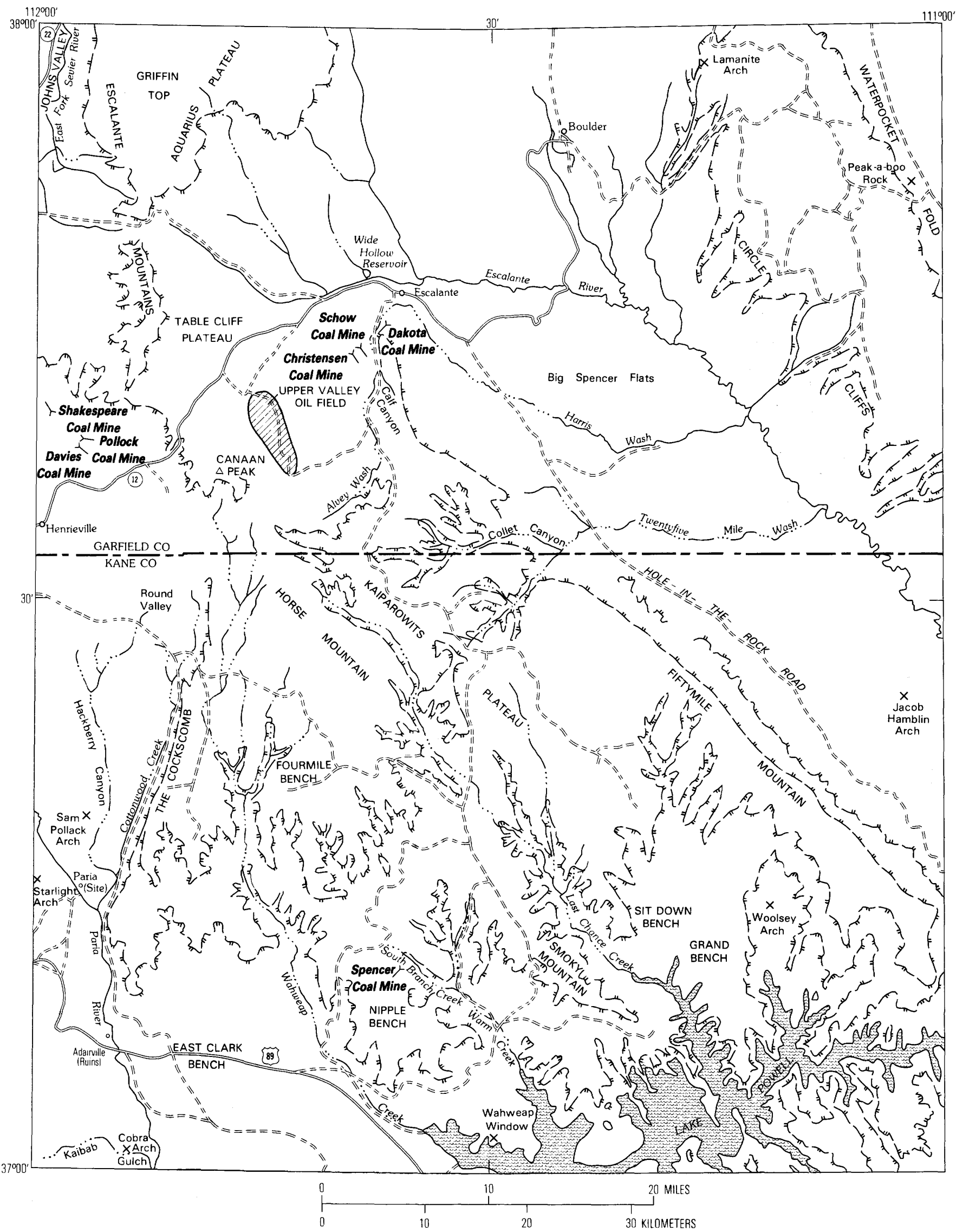

Figure 3. Kaiparowits coal-basin area showing locations of physical and cultural features commonly referred to in text. 


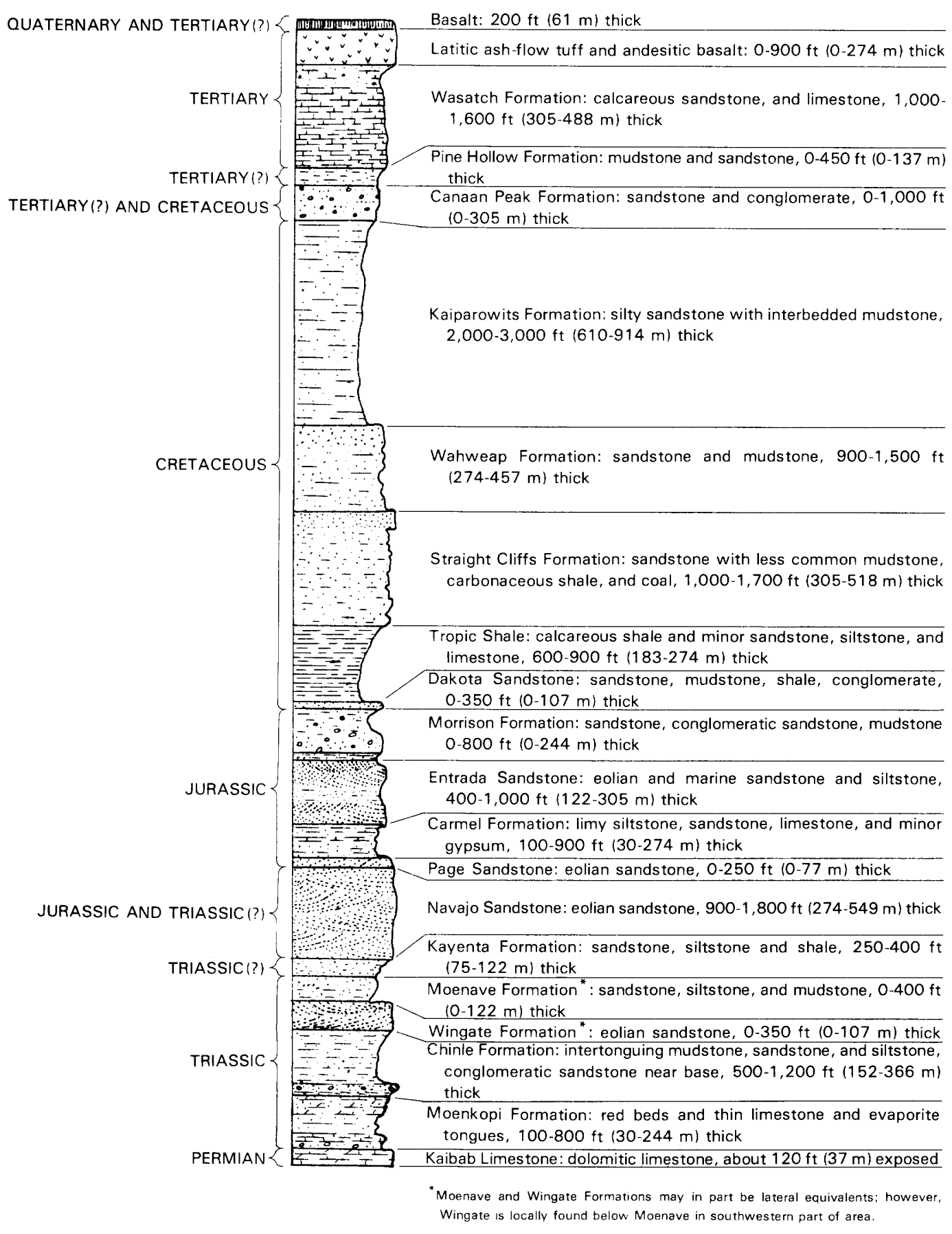

Figure 4. Generalized composite stratigraphic section of exposed rocks in the Kaiparowits area.

\section{Sedimentary Rocks}

Thickness of the aggregate exposed sedimentary section exceeds $10,000 \mathrm{ft}$ in the Kaiparowits Plateau area. The section consists mostly of nonmarine sandstone, siltstone, and mudstone, and marine shale. Conglomerate, limestone, dolomite, gypsum, and coal are common lo- cally. Many of the sandstone units are crossbedded or irregularly bedded, moderately friable, and light gray to tan, or pink. Many formations or units of equivalent age exhibit little lithologic variation across the area, although a notable exception exists in the transition of the nonmarine Straight Cliffs Formation under the Kaiparowits Plateau on the west to the middle and upper parts of the 
Mancos Shale, which is marine to near-shore marine to the east, in the vicinity of the Henry Mountains. A significant increase occurs in the limestone and gypsum content of the Jurassic Carmel Formation from north to south across the Circle Cliffs and from east to west across the Kaiparowits map area. Complex facies changes and stratigraphic correlations occur in Triassic and Jurassic units as well as in some lower Tertiary sedimentary rock units.

\section{Igneous Rocks}

Sequences of Quaternary and Tertiary basaltic-toandesitic lava flows and latitic ash-flow tuffs are 500$1,000 \mathrm{ft}$ thick. These rocks were erupted mainly in the high plateaus but locally are present at lower elevations as a result of faulting and gravity sliding.

\section{STRUCTURE}

The bedrock exposures of south-central Utah are exceptionally good; they allow geologists to interpret the major and most of the minor structural features. The Kaiparowits coal-basin area has not only the large-scale deformational features such as the monoclines of the Waterpocket Fold and The Cockscomb (East Kaibab monocline), the anticlines of the Circle Cliffs and Kaibab (west of The Cockscomb) upwarps, and the large downwarps of the Henry basin and Kaiparowits Plateau, but also more numerous, smaller scale versions of these deformational features (fig. 5). Mapped on a geologic datum, the portrayed deformational features give the impression of a large area of crenulated strata broken only rarely by faults of small displacement.

To the east, the Waterpocket Fold (fig. 5), a monocline, extends northwest-southeast for about $90 \mathrm{mi}$ as a $1-$ to $2-$ mi-wide band of tilted rocks that dip from $3^{\circ}$ to $49^{\circ}$ northeast. Immediately east of this large monocline is the Henry basin; immediately west of the monocline is the Circle Cliffs upwarp, a large and elongated anticline about $65 \mathrm{mi}$ long (Davidson, 1967, p. 59). Amplitude of folding is at least $8,000 \mathrm{ft}$, measured from the crest of the Circle Cliffs anticline to the deepest part of the Henry basin. Ages of the exposed strata involved in the folding range from Permian to Late Cretaceous. Faults in this area of the Waterpocket Fold are usually small, normal faults.

Between the Circle Cliffs upwarp and the basin under the Kaiparowits Plateau are a series of smaller anticlines and synclines. Largest of the fold features are the Harris Wash syncline, the Escalante anticline, and the Escalante monocline. Although relatively short in length, the
Escalante anticline and monocline together are an impressive feature with an amplitude of about 4,500 ft of folding. Most of the exposed strata involved in the folding are of Triassic and Jurassic age (Navajo Sandstone and the overlying Carmel Formation).

Farther west are a series of crenulations within the Kaiparowits basin. Perhaps the most striking fold features are the Upper Valley anticline and the adjacent Dutton monocline (both of which extend for $25 \mathrm{mi}$ on a northwest-southeast trend). Other large folds are the Table Cliff, Wahweap, Last Chance Creek, and Alvey Wash synclines (fig. 5). The age of the surface strata involved in folding of these features is Late Cretaceous, but Eocene to Miocene age rocks overlie the Cretaceous in marked angular unconformity and they too are slightly downwarped in the vicinity of the Table Cliff syncline. Farther south, the Rees Canyon anticline, Last Chance Creek syncline, Smoky Mountain anticline, Glen Canyon syncline, and the north end of the Echo monocline involve rocks as old as the Triassic(?) and Jurassic Navajo Sandstone. Several small normal faults occur in the southernmost part of the Kaiparowits basin. North of the Kaiparowits Plateau several normal faults have been mapped in the area where the Kaiparowits structural basin extends beneath Table Cliff Plateau and the Escalante Mountains (fig. 3). There faults transect the flatlying volcanic rocks of Miocene age as well as the folded Mesozoic strata.

Between the Kaiparowits basin and Kaibab upwarp is the East Kaibab monocline (The Cockscomb). This large monoclinal fold has structural relief of about 5,500 $\mathrm{ft}$ in a horizontal distance of less than $4 \mathrm{mi}$. Exposed rocks folded in the monocline range in age from Late Cretaceous (Kaiparowits Formation) to Permian (Kaibab Limestone). The fold plunges northeast. Numerous small normal faults occur along the East Kaibab monocline and some occur on the Kaibab upwarp. The upwarp is bounded on the west by the Paunsaugunt fault zone, which has a maximum throw of at least $2,000 \mathrm{ft}$. Strata involved in the faulting range in age from the Triassic(?) and Jurassic Navajo Sandstone to the Paleocene and Eocene Wasatch Formation, and farther north, volcanic rocks of Miocene age, as seen on the geologic map of the Kaiparowits Plateau (Sargent and Hansen, 1982).

This deformation can be dated by the map relations of the strata (Bowers, 1973c) as Late Cretaceous to early Paleocene-about 70,000,000 years old. The earliest deformation began after deposition of the Upper Cretaceous Kaiparowits Formation and ended before deposition of the Paleocene and Eocene Wasatch Formation. Soon after the end of the folding, the deformed strata were beveled to a relatively smooth surface that was probably not very much above the base level of erosion.

Early Tertiary erosion in the Kaiparowits area ended with gradual development of a large basin in which mixed 


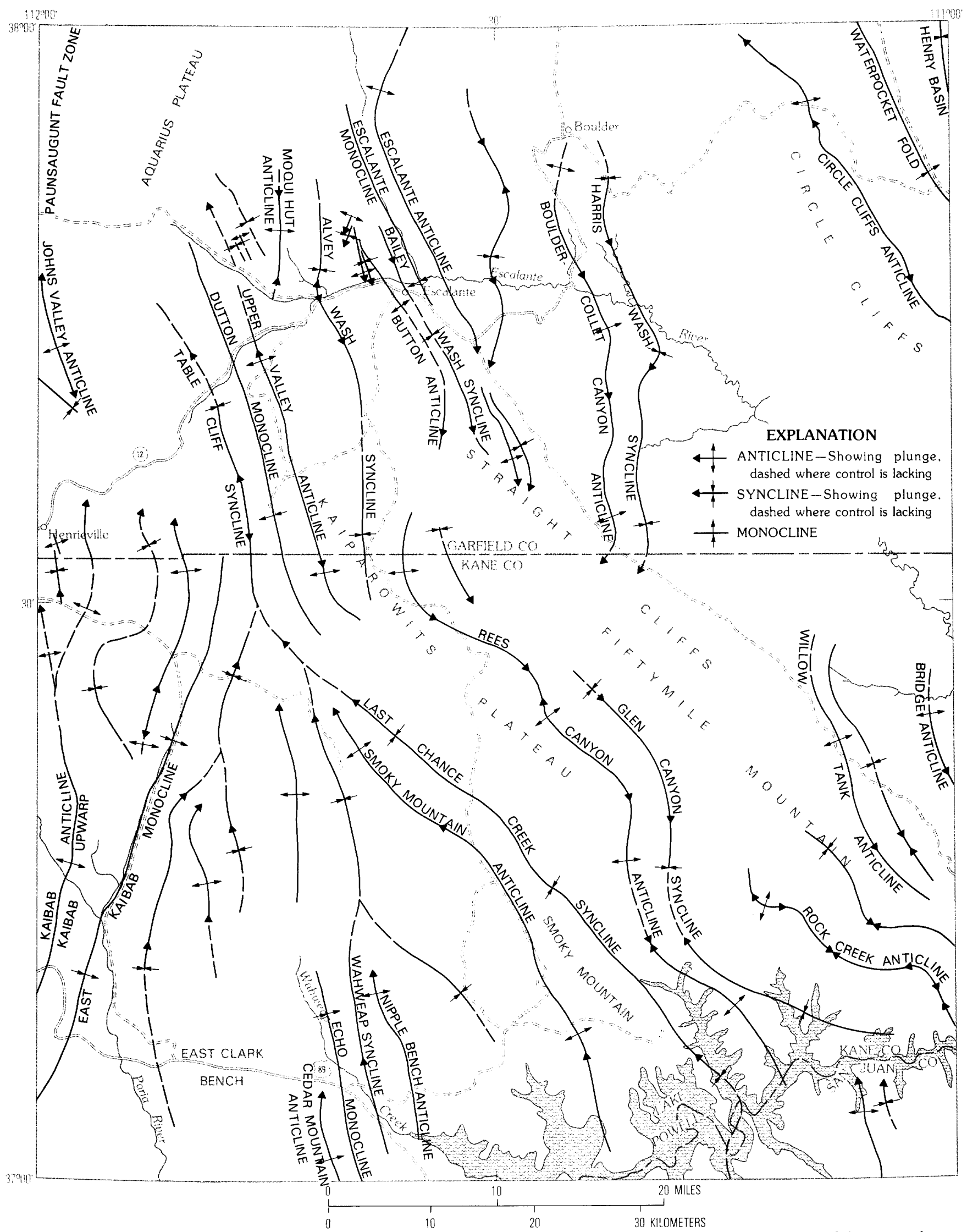

Figure 5. Kaiparowits coal-basin area showing structural geology features referred to in text (modified from Hackman and Wyant, 1973). 
fluvial and lacustrine strata of the Wasatch Formation were deposited (Bowers, 1972). After deposition of the Wasatch and related strata, uplift resumed throughout the entire area and the strata were probably beveled again to a relatively smooth northward-sloping surface. In Eocene(?), Oligocene, and early Miocene time, ash-flow tuffs and lava flows were deposited in the Aquarius Plateau area and on the plateaus farther north and west. By early middle Miocene, the entire area was subjected to normal faulting and the Paunsaugunt fault zone may have shown flexuring and some displacement. Most of the displacement along the Paunsaugunt fault zone was probably later. By mid-Miocene time, the entire Colorado Plateau started to rise relative to base level, and the cycle of canyon erosion that is still active began. Despite the magnitude of canyon erosion, large areas of Upper Cretaceous coal-bearing rocks have been preserved within synclinal and basinal structures. In a regional view the coalbearing rocks are preserved within the Kaiparowits Plateau basin and its northern extension under the Aquarius Plateau.

\section{ECONOMIC GEOLOGY AND HISTORY OF COAL DEVELOPMENT}

Coal is the single most valuable mineral resource in south-central Utah. The Kaiparowits coal basin has been studied by workers for many years and is known to contain large reserves in the Cretaceous section. Other resources in the area include oil, which has been produced in commercial quantity since 1964 from Permian and Triassic rocks in the Upper Valley field (fig. 3) west of Escalante. Elsewhere only shows of oil or gas have been reported. The rocks of the study area are only slightly mineralized. Some sandstones and shales contain small deposits of uranium, minor gold, titanium, selenium, arsenic, antimony, thorium and rare earths, and manganese, and small amounts of low-grade copper. Aggregate, "clinker" (rock baked by burning coal), silica, and semiprecious gem materials are locally abundant. Sandstone for building is abundant, and some clay deposits are known. Gypsum is widely distributed and may locally be of commercial grade. Limestones suitable for industrial use and chemical applications are present but not common. The mineral deposits mentioned above are summarized in more detail in Sargent and Hansen (1976).

Soon after the settlement of Escalante in 1876, the records show coal being mined south of town in the Alvey Wash area. The Christensen and Schow mines (fig. 3) were reported active at least as early as 1893 . Within $5 \mathrm{mi}$ of Escalante, about eight coal mines were supplying coal to local residents in the 1920's (Gregory and Moore, 1931). The Spencer coal mine was opened in 1913 in the southern Kaiparowits Plateau area on South Branch
Creek (fig. 3). Coal from that mine was transported by wagon and pack horse, and finally by barge down the Colorado River to the site of an abortive gold mining operation near the mouth of the Paria River (Averitt and Cashion, 1965). North of Henrieville, the Pollock, Shakespeare, and Davies mines (fig. 3) supplied local needs to settlements west of the plateau as late as 1964 .

Coal on the Kaiparowits Plateau occurs in the Dakota Sandstone and the Straight Cliffs Formation. In the Dakota Sandstone (Hansen, 1978a) are thin coal seams. One such thin seam crops out $5 \mathrm{mi}$ south of Escalante at the base of the Straight Cliffs. According to H. D. Zeller (written commun., 1978), wooden rails used for coal transport at a mine that worked this seam could be seen as late as 1965. Major coal zones in the Kaiparowits Plateau are chiefly in the John Henry Member of the Straight Cliffs Formation (fig. 6). These zones extend under much of the plateau at depths prohibitive to strip mining (Hansen, 1978a), so that most of the coal could be extracted only by underground mining unless suitable coal gasification or liquefication processes are developed in the area.

The quality of coal in the John Henry Member varies from subbituminous $\mathrm{C}$ to high-volatile bituminous $\mathrm{A}$. The average sulfur content is relatively low $(0.87$ percent); the range is 0.26 to 3.40 percent. The heat value averages $11,999 \mathrm{Btu} / \mathrm{lb}$; the range is 8,499 to $14,236 \mathrm{Btu} /$ lb (Doelling and Graham, 1972, p. 93).

In 1965 , a consortium of utility companies proposed a plan to build a 5,000 megawatt coal-burning power plant, at a cost of $\$ 500$ million. In the mid 1970's after much controversy over environmental issues, a new plan was proposed for a 3,000 megawatt generating plant, mine, and community to house miners, electrical plant workers, and attendant service personnel. The total cost of this plan was to have been about $\$ 3.5$ billion. The impacts as cited in the 1967 Environmental Impact Statement (U.S. Bureau of Land Management, 1976) for this plan include degradation of air quality, land subsidence above the coal mine, marked increase in population, reduced grazing, degradation of recreational experience at Lake Powell and surrounding parks and scenic areas, and mercury release into Lake Powell from plant emissions. Environmental challenges continued, and in April 1976, two of the three major partners in the Kaiparowits Power Project, San Diego Gas and Electric Co. and Southern California Edison Co., announced that they were dropping construction plans because of government action and pending lawsuits. Despite delays, an agenda for development at Kaiparowits still exists. Presently active in exploration and the outlining of reserves are the El Paso Company and Mono Power Company et al. (Resources Company, wholly owned subsidiary of Arizona Public Service Company, New Albion Resources Company, wholly owned subsidiary of San Diego Gas and Electric Com- 


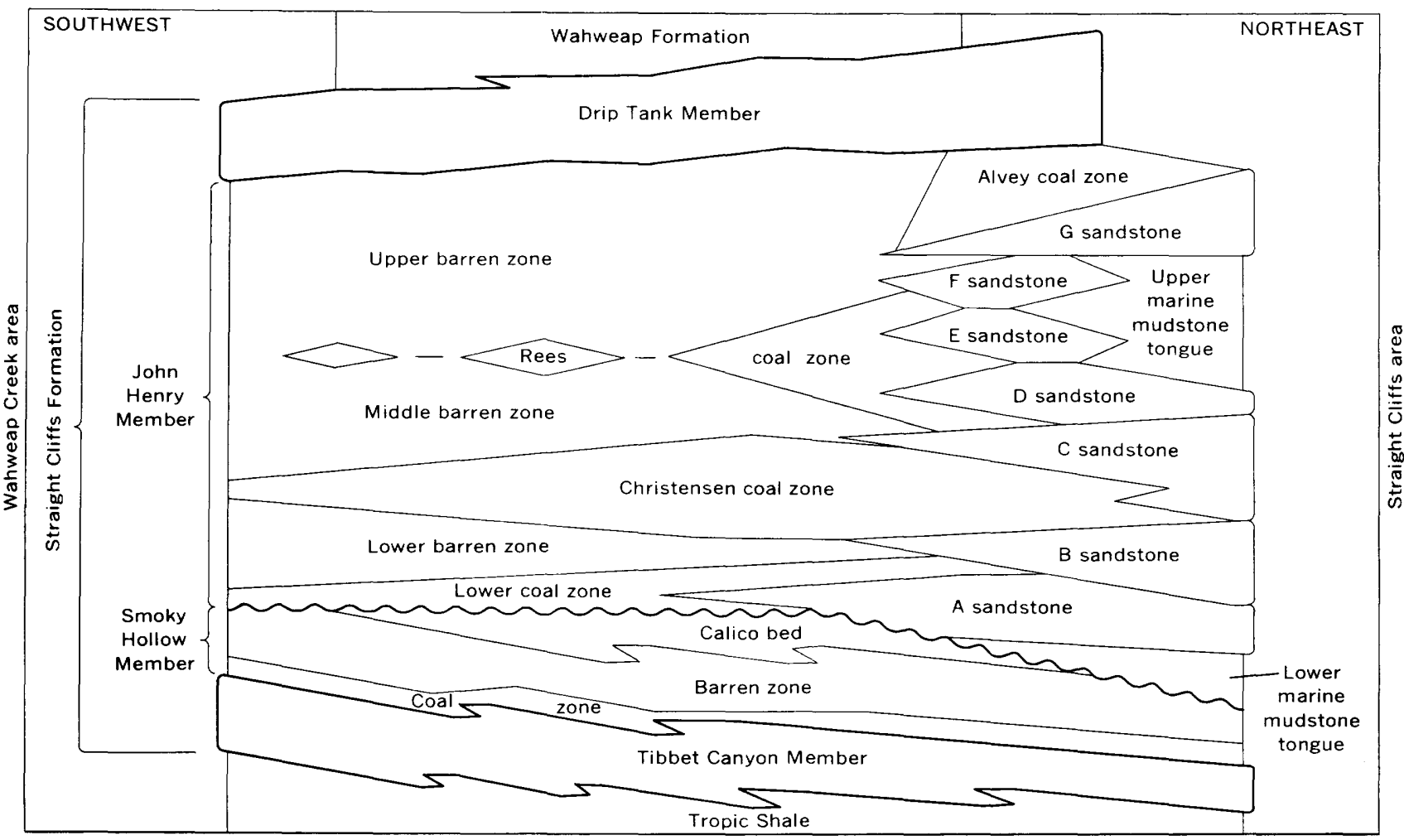

Figure 6. Relations of members and informal units in the Straight Cliffs Formation-southeast Kaiparowits Plateau coal field. Approximately $30 \mathrm{mi}$ from left to right. (From Peterson, 1969, p. J8.)

pany, and Mono Power Company, wholly owned subsidiary of Southern California Edison Company).

Plans of the two development entities, which are ambitious, envisage shipment of coal to distant users by truck, conveyors, rail, and (or) slurry line. El Paso Coal Company proposes production from two underground mines; one to produce 200 million tons of coal over a 38-year mine life, the other to produce 4.5 million tons over a 10-year mine life. Mono Power Company et al. proposes to mine 12 million tons of coal per year from five underground mines with a mine life of 35 years. Environmental statements covering regional and site specific analyses have been prepared by the U.S. Department of the Interior (1979).

\section{MAPS OF THE KAIPAROWITS COAL-BASIN FOLIO}

The U.S. Geological Survey has prepared 12 maps of the land resources of the Kaiparowits coal-basin area designed to furnish an information base for environmental decisions on development of the coal resources of the area. These maps (I-1033-A through I-1033-L) are either published or in press. The following section summarizes the content of each map. Data cited are in the primary units of measurement used by the map authors.

\section{Hydrologic Maps}

Four hydrologic maps recently published on the Kaiparowits coal-basin area give an overview and up-todate summary of known water resources for the area.

\section{General Chemical Quality of Ground Water}

Data for this map (Price, 1977a) were obtained by the chemical analyses of water samples from about 40 springs, 20 coal-exploration drill holes, and 7 water wells. Ground water in most of the Kaiparowits area is fresh to slightly saline (classification in Hem, 1970, p. 219). The most potable water is located at the headwaters of the Escalante River, along reaches of Hackberry Canyon and Cottonwood Creek, and in the vicinity of Lake Powell (fig. 3). In these areas Price (1977a) noted that springs sampled commonly contain less than $500 \mathrm{mg} / \mathrm{L}$ of dissolved solids and have the Navajo Sandstone, the Wasatch Formation, or Tertiary volcanic rocks as their sources. The most saline areas, where water has 1,000 to 10,000 $\mathrm{mg} / \mathrm{L}$ dissolved solids, are along the southern margin of the Kaiparowits Plateau, in the Henrieville-Round Valley area, and in the northeast part of the map area. In each of these areas, the Tropic Shale is the source of the high dissolved solids. The quality of ground water in the area on the plateau underlain by coal is fresh (100 to 1,000 
$\mathrm{mg} / \mathrm{L}$ ) northward from Canaan Peak and fresh to slightly saline (500 to $3,000 \mathrm{mg} / \mathrm{L}$ ) southward from Collet Canyon. Locally, water of higher and lower salinity occurs on the plateau.

\section{General Availability of Ground Water}

Data for this map (Price, 1977b) were obtained from records of water wells, springs, coal and petroleumexploration holes, previously unpublished reports, and field work by Don Price. Ground water occurs at varying depths in all the sedimentary and volcanic rocks of the Kaiparowits coal-basin area. Locally, ground water occurs in stream valley alluvium; terrace gravels and dune sands are largely unsaturated. Price (1977b) reported that in the vicinity of the town of Escalante and in Johns Valley (fig. 3), individual wells tapping alluvium could yield as much as $500 \mathrm{gal} / \mathrm{min}$ of water, but in most places alluvium is discontinuous and too thin to yield more than $50 \mathrm{gal} / \mathrm{min}$ on a sustained basis. Volcanic rocks yield water to numerous springs on the Aquarius Plateau. Price believed that wells in the volcanic rocks could yield as much as 50 $\mathrm{gal} / \mathrm{min}$ and possibly more if wells were ideally located.

Most of the ground water available for development in the Kaiparowits area is contained in the thick section of sedimentary rocks underlying the Kaiparowits Plateau. This section of rock averages more than $6,000 \mathrm{ft}$ thick throughout the area, and locally exceeds $12,000 \mathrm{ft}$ thick (Lidke and Sargent, 1983). Despite a substantial content of water, many of the beds have low permeability and would transmit water slowly to wells and springs, except where rocks are fractured or faulted. A notable exception is the Navajo Sandstone, which is a good aquifer and an ideal source of ground water where it is near the surface. Although most of the sedimentary rocks would yield only from 5 to $50 \mathrm{gal} / \mathrm{min}$ to individual wells, the Navajo Sandstone would generally yield more than $50 \mathrm{gal} / \mathrm{min}$, and might yield more than $1,000 \mathrm{gal} / \mathrm{min}$.

The depth to ground water shown on the availability of ground water map (Price, 1977b) is to the top of the main zone of saturation (the regional water table). Perched ground-water tables may occur at varying levels above the main zone of saturation, but wells into perched water tables can be expected to produce only limited amounts of water and should not be considered to have sustained capacity. Springs are numerous in the headwaters of the Escalante River, especially around the Aquarius Plateau, whereas they are sparse in the Circle Cliffs area. Yields from springs typically range from less than 1 to about $20 \mathrm{gal} / \mathrm{min}$, but several discharge more than $100 \mathrm{gal} / \mathrm{min}$.

\section{Principal Drainage Basins, Principal Runoff-Producing Areas, and Selected Streamflow Data}

The Kaiparowits coal-basin area is divided into three drainage basins: (1) about 85 percent of the area drains into Lake Powell via Escalante River and Wahweap, Warm, and Last Chance Creeks; (2) 11 percent of the area drains to the Paria River, which drains to the Colorado River below Lake Powell; and (3) the remaining 4 percent drains into the East Fork Sevier River, which drains northward to the Sevier River and the Great Basin (Price, 1978). In the map area, only the Escalante River is a perennial stream, and except for small stream segments and some minor drainages, all other streams are intermittent. The Paria River and the East Fork Sevier River are intermittent in the map area, but are perennial in upstream and downstream reaches off the map area. Rainfall normally ranges from 6 in. per year along the shore of Lake Powell to about 30 in. in the headwaters of the Escalante River. Runoff in those areas ranges from less than 0.5 in. near Lake Powell to about 10 in. in the upper Escalante River area. Runoff occurs mostly in April, May, and June, which is the rainy season as well as the time of melting of winter snows. Floods from summer thunderstorms and cloudbursts may generate more than $3,000 \mathrm{ft}^{3} / \mathrm{s}$ in drainage areas of less than $100 \mathrm{mi}^{2}$. The largest recorded flood in the area was measured near Adairville on the Paria River in August 1963, when $15,400 \mathrm{ft}^{3}$ of water per second was discharged.

\section{General Chemical Quality of Surface Water}

The interpretation of the chemical quality of surface water in the Kaiparowits coal-basin area (Price, 1979) is based on chemical analyses of about 130 water samples collected during low runoff periods from 1972 to 1975 , on information on the chemical quality of ground water, and on local geology. Runoff in the area generally ranges from fresh (less than $1,000 \mathrm{mg} / \mathrm{L}$ dissolved solids) to moderately saline $(3,000$ to $10,000 \mathrm{mg} / \mathrm{L}$ dissolved solids) - the maximum concentration of dissolved solids recommended by the U.S. Public Health Service (1962, p. 7) for drinking water is $500 \mathrm{mg} / \mathrm{L}$. However, where fresher water is unavailable, water with more than 1,000 $\mathrm{mg} / \mathrm{L}$ is used. Runoff is freshest in the headwaters of the Escalante River, and has a dissolved-solids concentration of generally less than $250 \mathrm{mg} / \mathrm{L}$ even during low-flow periods. Runoff is most saline along the lower reaches of Wahweap, Warm, and Last Chance Creeks, and contains dissolved-solids concentration of generally more than $3,000 \mathrm{mg} / \mathrm{L}$. High salinity of the runoff in the Kaiparowits coal-basin area is caused by a concentration of salts leached from the soil during irrigation (especially common in return flows to the Paria and Escalante Rivers), seepage of saline ground water to streams (especially in or downstream from outcrops of the Mancos and Tropic Shales), and evapotranspiration (direct evaporation and transpiration by vegetation) along water courses.

Runoff water in the upper reaches of the Escalante River and in most other areas where dissolved-solids concentrations are generally less than $500 \mathrm{mg} / \mathrm{L}$ is of a calci- 
um bicarbonate type. Runoff water in other areas is generally of a calcium sulfate or sodium sulfate type.

Dissolved-solids concentrations on Lake Powell water range from 500 to $1,000 \mathrm{mg} / \mathrm{L}$ (1976 salinity level). Although Wahweap, Warm, and Last Chance Creeks discharge moderately saline water into Lake Powell, the total annual salt load contributed to the lake by those streams is relatively small, probably only about 0.3 percent of the total estimated salt load added to the lake by the Colorado and San Juan Rivers under 1974 conditions (modified) (Price, 1979).

\section{Coal Resource Maps}

Coal Extent and Thickness, and Amount of Overburden on Major Coal Zones

Two coal resource maps constitute a major part of the Kaiparowits coal-basin area folio; one shows extent and total thickness of coal beds (Hansen, 1978a), and another shows amount of overburden on major coal zones (Hansen, 1978b). These maps give a general overview of coal resources of the Kaiparowits coal basin. Coal studies by the Utah Geological and Mineral Survey (for example, Doelling and Graham, 1972) and the U.S. Geological Survey (for example, Bowers, 1973a, and Zeller, 1973a) should be used where more detail is required.

The coal in the Kaiparowits Basin is of Late Cretaceous age and is found in the Dakota Sandstone and the Straight Cliffs Formation. The Dakota Sandstone and the lower part of the Straight Cliffs Formation contain only discontinuous beds of coal and carbonaceous shale, but the John Henry Member of the Straight Cliffs Formation contains major coal deposits in at least five zones. In ascending order, these are: (1) lower coal zone, (2) Henderson coal zone, (3) Christensen coal zone, (4) Rees coal zone, and (5) Alvey coal zone. The Christensen and Alvey zones are generally considered to be most important, although the lower, the Henderson, and the Rees are locally of economic interest.

The thickest coals in the John Henry Member occur in a northwest-trending belt $10-15 \mathrm{mi}$ wide that goes through the center of the Kaiparowits coal basin. Hansen (1978a) showed a total thickness of 14.3 to $29.2 \mathrm{~m}$ of coal in the southern part of this belt and 28.9 to $42 \mathrm{~m}$ in the northern part.

Hansen's second map (1978b) shows amount of overburden on two major coal-bearing zones: the combined Christensen and Henderson and the Alvey. This map shows four categories of overburden thickness: (1) less than $300 \mathrm{~m}$, (2) $300-600 \mathrm{~m}$, (3) $600-900 \mathrm{~m}$, and (4) greater than $900 \mathrm{~m}$. Examination of this map shows that limited stripping operations west of Escalante and a few miles south of Utah Highway 12 may be feasible, but most of the coal-basin area is only amenable to under- ground mining. Areas with the least amount of overburden are on the east and south sides of the plateau where thick zones of coal lie at depths of less than $300 \mathrm{~m}$.

A large area of potentially minable coal extends from about $10 \mathrm{mi}$ south of Canaan Peak northwestward as far as $30 \mathrm{mi}$; this coal area, however, is buried in excess of $900 \mathrm{~m}$.

\section{Landform Map}

This map (Sargent and Hansen, 1980) portrays the shape and ruggedness of the terrain. The bedrock consists of gently dipping sedimentary rock layers that have eroded back away from the Colorado River Valley (Lake Powell) in a series of steps that form a giant staircase. Each step is shown on the map as a set consisting of light map colors for flatlands and dark map colors for steep canyons or cliffs. From south to north the steps are progressively higher; each step represents successively higher rocks in the geologic column. Terrain with intermediate slopes is patterned for recognition. Other landform features include hogbacks and depositional units. Hogbacks are those features formed where sedimentary rocks are sharply upturned by folding, and eroded into sharp ridges (fig. 7). Such features can be found in the northeast corner of the map area along the Waterpocket Fold and in the southwest corner of the area along The Cockscomb (or East Kaibab

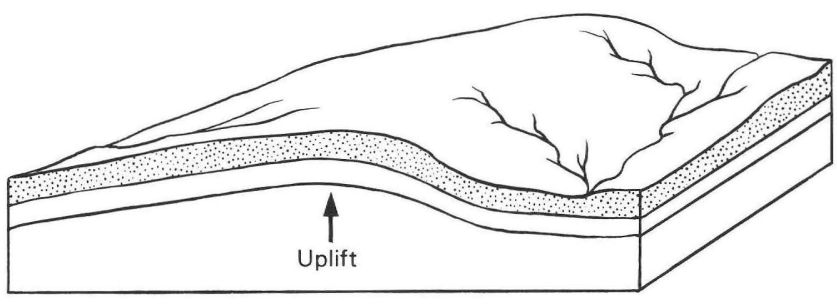

A

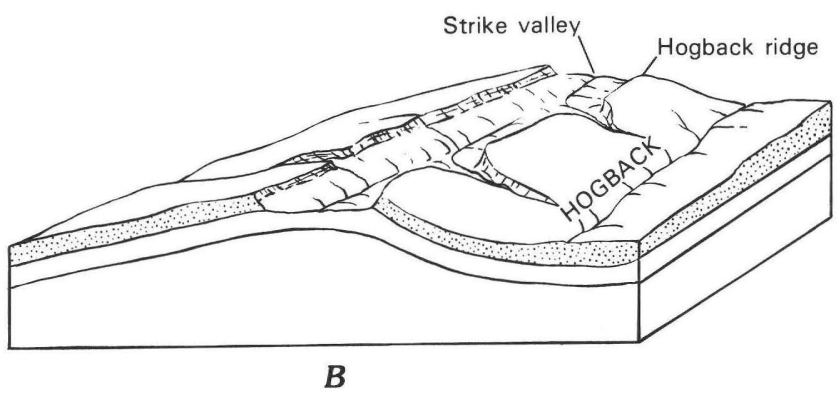

Figure 7. Formation of hogbacks by $A$, arching of stratified rocks; and $B$, subsequent erosion that leaves resistant ridges or hogbacks on hard rock units and strike valleys on less resistant rock units. 
monocline). Depositional units are composed of unconsolidated sediments and include areas of valley fill or alluvium, sand dune fields, and pediment gravels. These units lie as veneers on top of the bedrock and because of their even surfaces are commonly the best transportation routes across rough terrain.

Off-road vehicular travel across hogbacks is difficult to impossible, whereas travel parallel along strike valleys is generally easy. Locally, low gaps allow vehicle crossing of the ridges from one strike valley to another. Alluvial flats and stream courses commonly afford the best routes to cross intermediate-slope and cliff units of the staircase topography (fig. 8).

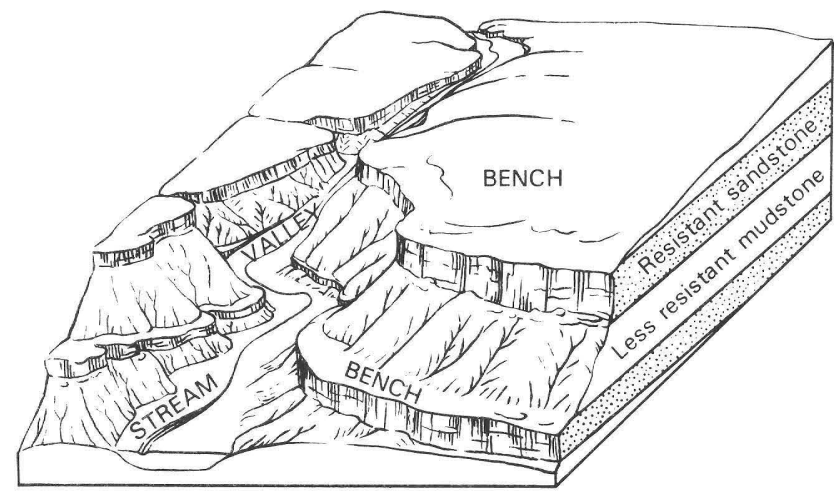

Figure 8. Sketch of stream valley floored with unconsolidated fill which serves as a transportation route to cross from one bench level to another.

\section{Landslide Map}

This map (Fuller and others, 1981) provides a general indication of potential hazard from landsliding and rockfall in the Kaiparowits coal-basin area by identifying areas affected by those processes in the past. Landslides tend to recur in the same areas over thousands of years; relatively few landslide events can be expected to occur in new areas. Recently active landslides, those that have moved significantly in the last few thousand years, are the most probable sites for future movement, and these areas are shown as a special unit within the mass of older slides. Debris flows associated with recent landslides have extended far beyond the toes of slides, and buried vast areas of gentle slope where existence of such a hazard is not obvious. These areas are also depicted on the map. Areas affected by rockfall include all steep cliffs as well as accumulations of fallen rock. Probability of new rock falls in these areas must be considered high. In some areas of older landsliding, topographic and climatic changes have stabilized the slopes, so that the risk of recurrent movement is low. Thus some sites within the older landslide unit are stable enough for some kinds of construc- tion, although engineering analysis and certain precautions may be necessary.

Areas of most extensive landsliding and debris flow occur along the steep slopes of the Kaiparowits and Aquarius Plateaus. Here, shales and relatively unresistant, poorly consolidated sedimentary rocks are overlain by more resistant sandstones (on the Kaiparowits Plateau) and volcanic rocks (on the Aquarius Plateau). Because of the overlying more competent caprock, the slopes tend to be oversteepened in the underlying less consolidated sediments, thereby forming a situation ideal for slope failure, especially in the higher areas of the Kaiparowits and Aquarius Plateaus where precipitation is greater. Landslides do not pose a serious problem in much of the interior of the Kaiparowits Plateau coal basin. However, under the south and east rims of the Kaiparowits Plateau (fig. 9) adjacent to Nipple Bench, Smoky Mountain and Fifty-

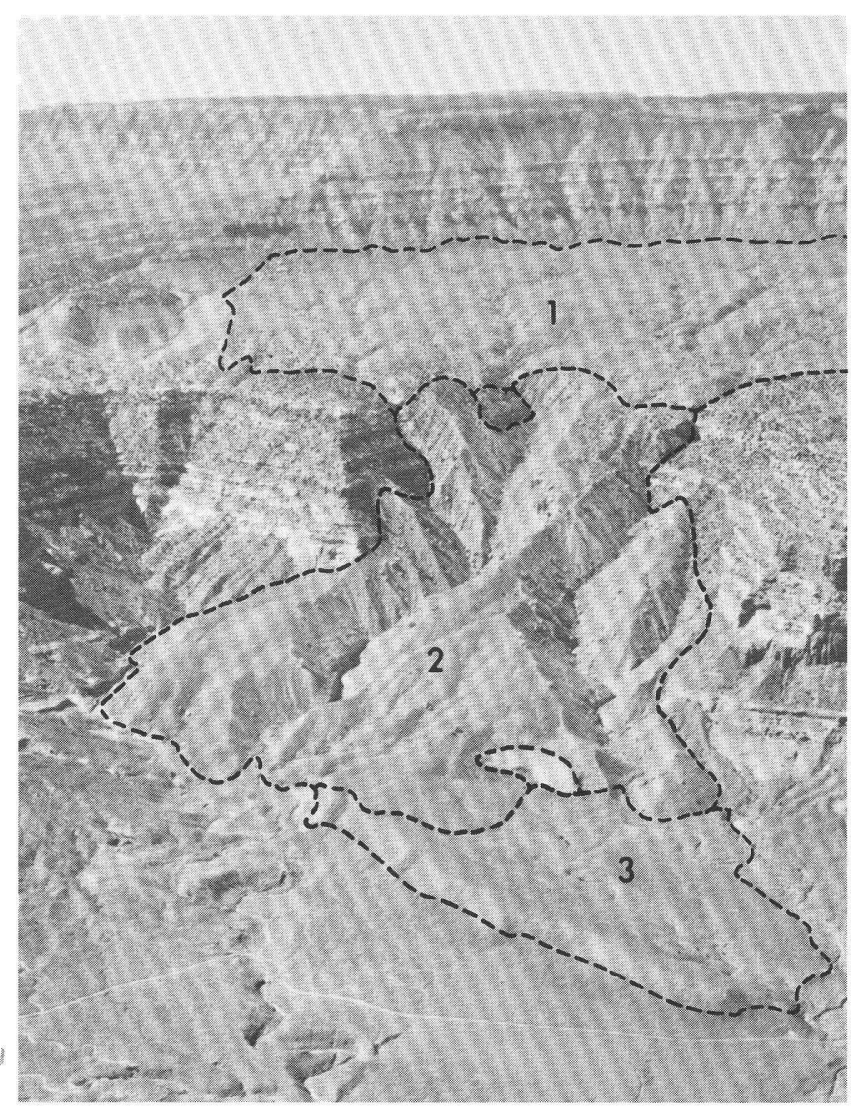

Figure 9. Oblique aerial photograph of landslide debris. Photograph taken just north of Fiftymile Point looking west near south end of Fiftymile Mountain. Landslide and debris-flow material has moved toward viewer from near base of highest cliffs onto intermediate bench of Dakota Sandstone as a sheet slide (1) and locally has flowed down over Morrison-Entrada cliffs as a lobate debris slide (2). Boulders in debris slide are as large as 40 ft. Debris flow (3) formed at lower end. Landslide data from V. S. Williams (written commun., 1981). Photograph by K. A. Sargent, 1976. 
mile Mountain (fig. 3), and in almost all the deeper canyons, rockfalls, landslides, and local debris flows are possible.

\section{Bedrock Geologic Map}

The map of bedrock geology (Sargent and Hansen, 1982) is a compilation and synthesis of all the known previous mapping and extensive new field observations. It depicts the geologic relations discussed previously under "Structure" and "Stratigraphy." Current stratigraphic usage is concisely summarized in the description of map units, and the locations of all the major fold axes are shown. In order to show bedrock relations better, this map omits surficial geologic deposits, which are the subject of a companion map by Williams (1984). Bedrock contacts that are buried by thick surficial deposits are dashed, reflecting the uncertainty of their location. This uncertainty is especially high east of Johns Valley and around the flanks of the Aquarius Plateau, where faulting, landsliding, and thick vegetation frustrate reliable projection of contacts. Elsewhere on the map, contacts have been placed as close as possible to their correct elevations in relation to contours on the topographic base. In a few places, where the contours are mislocated, it has been necessary to move contacts from their true planimetric position.

\section{Geologic Cross Sections}

Drill-hole and mapping data were combined to construct six generally east-west geologic cross sections

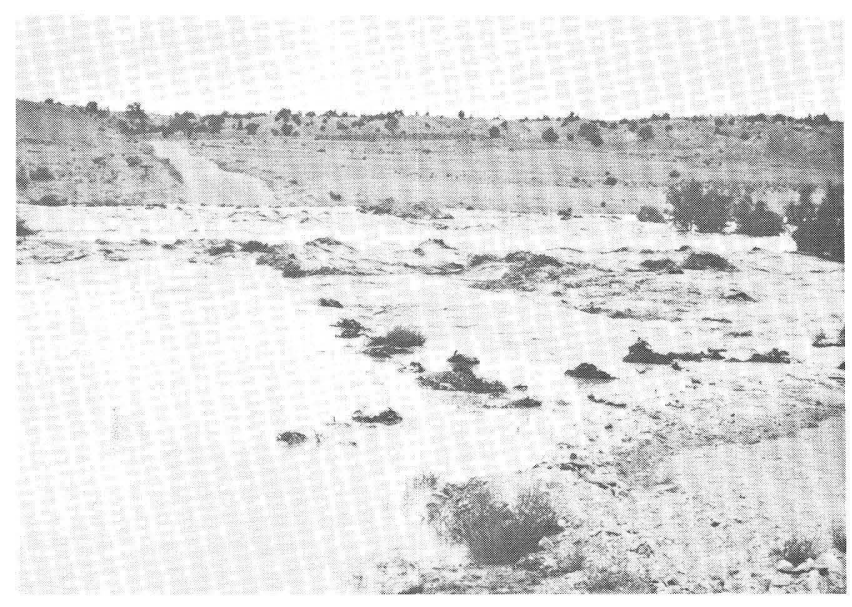

Figure 10. Flash flood on Twentyfive Mile Wash on Hole-in-the-Rock road, September 1977. Maximum water depth approximately $8 \mathrm{ft}$. Rain causing this flood fell 6-8 mi west (left) on Fiftymile Mountain. Photograph by L. M. H. Carter, 1977. which are perpendicular to the structural grain of the Kaiparowits Plateau (Lidke and Sargent, 1983). The major structural features depicted by these sections have been discussed previously under "Structure." No vertical exaggeration has been used, and the true amplitude of folding and dip of beds, which is locally substantial, is quite apparent.

All 94 known deep test holes in the general area of the Kaiparowits coal basin, including producing wells of the Upper Valley oil field, are located and described. Eight exceed 10,000 ft in depth, and the deepest (Tenneco No. 1 Griffin Point Unit 2) bottomed in Permian rocks at 14,117 ft. Only one drill hole (Tidewater No. 1 Kaibab Gulch) penetrates the bottom of the Paleozoic section. It was spudded in Permian rocks on the north end of the East Kaibab monocline just west of the map area (drill hole 93), and bottomed in Proterozoic Y, Shinumo Quartzite of the Unkar Group at 6,253 ft.

\section{Scenic Features Related to Geology}

This map (Carter and Sargent, 1983) depicts most of the land features of interest to people who wish to tour, hike, explore, or collect fossils, minerals, or rock specimens. The Kaiparowits area is diverse in having Lake Powell to the south for boating, swimming, and fishing, the beautiful slickrock canyon country for hiking and collecting in the central part, and high forested plateaus for hiking and fishing in the north.

The road net is updated to 1978. Some unmaintained roads may have deteriorated since then, owing to flash floods (fig. 10), landslides, or rockfalls.

Zones containing fossils and petrified wood (fig. 11)

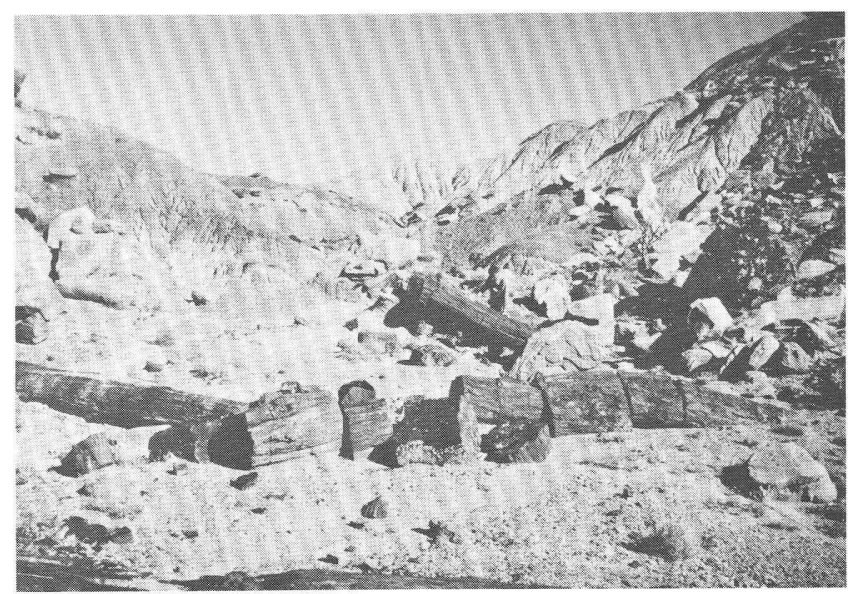

Figure 11. Petrified logs weathering from Petrified Forest Member of the Chinle Formation, northwestern part of Circle Cliffs. Man near center gives scale. Maximum log length about $36 \mathrm{ft}$. Photograph by K. A. Sargent, 1979. 


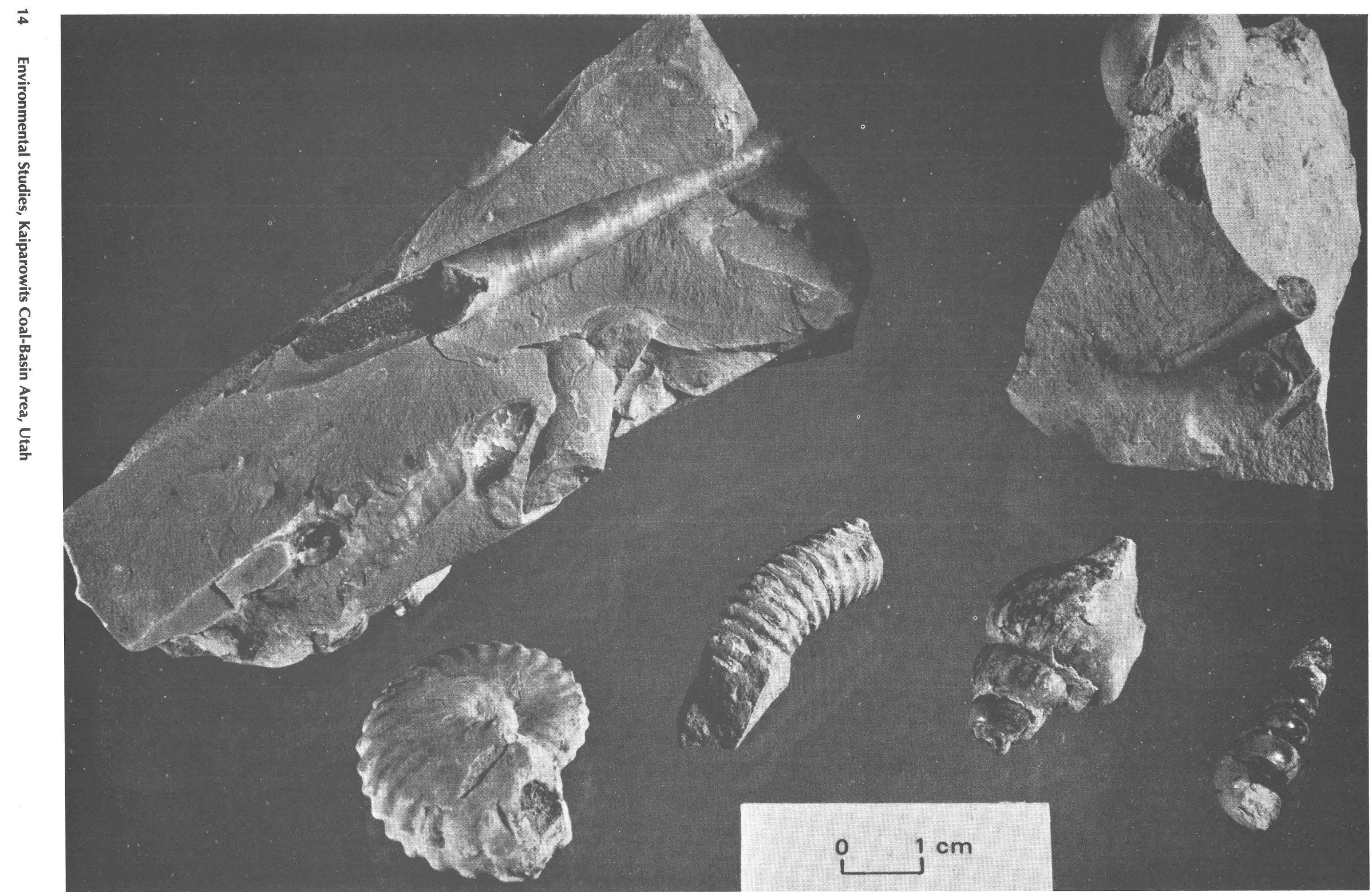

Figure 12. Typical mollusks from Sciponoceras zone, Tropic Shale, south of Escalante. Fossil assemblage is varied, but contains straight cone cephalopods, ammonites, gastropods, and pelecypods. Photograph by Dawn Reed, 1981. 


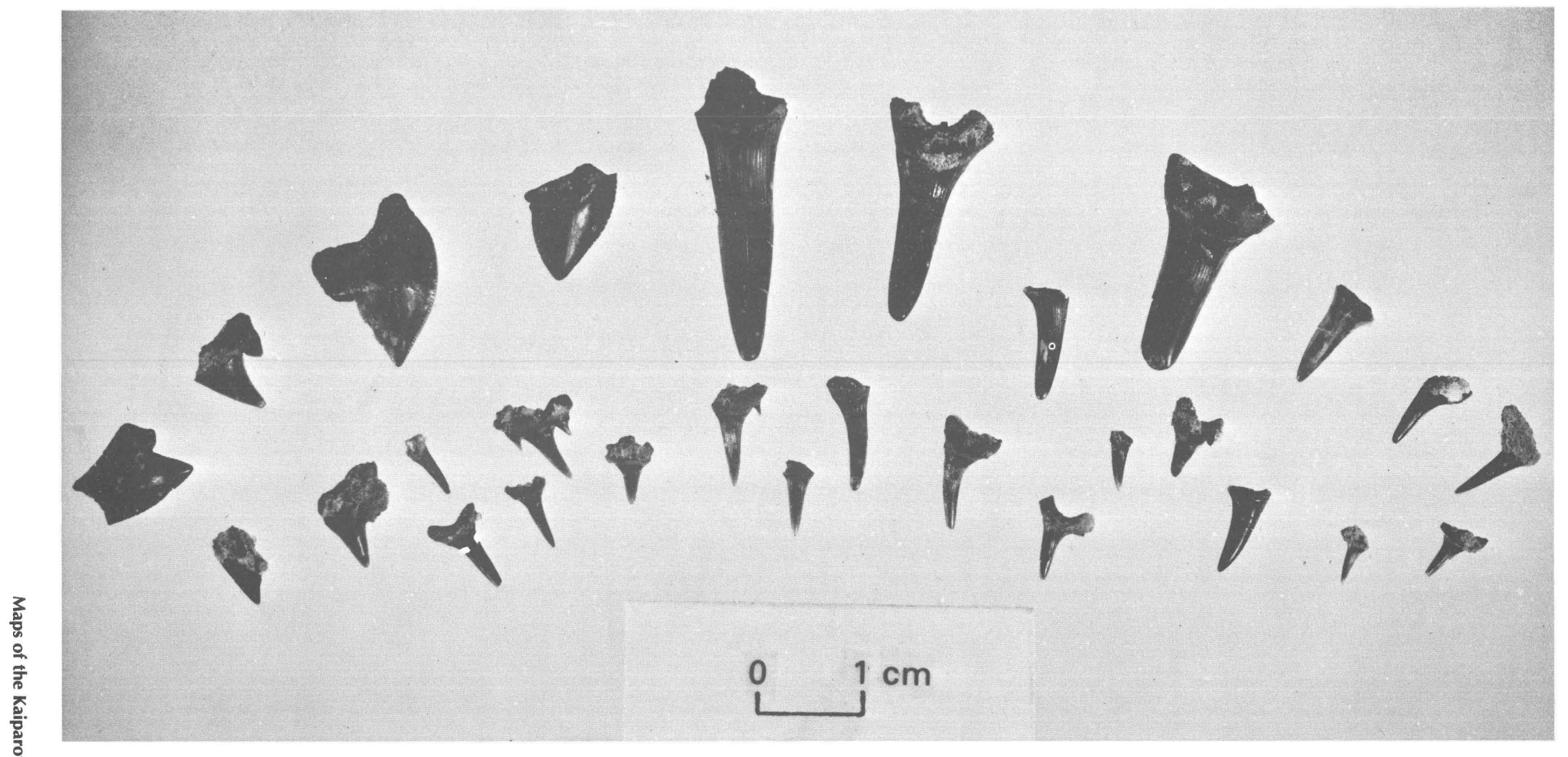

Figure 13. Cretaceous sharks teeth from Straight Cliffs Formation, Alvey Wash, southwest of Escalante. These teeth are from types that probably resembled today's sand shark and the long snouted "ghost shark." Photograph by Dawn Reed, 1981. 


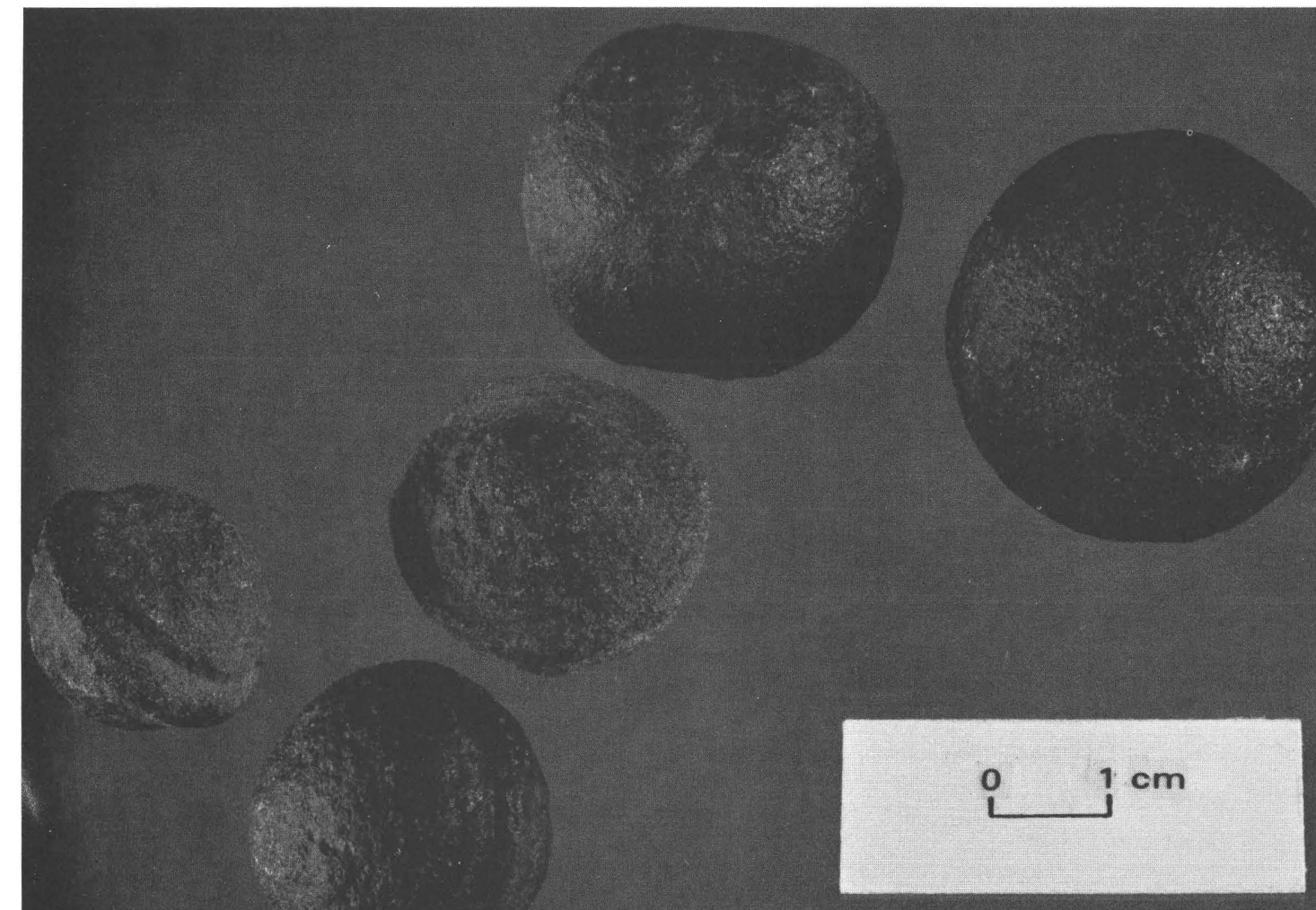

Figure 14. "Moqui marbles" or ironstone concretions from Big Spencer Flats, between Boulder and Escalante. These oddities weather out of the Navajo Sandstone and are presently very common. Photograph by Dawn Reed, 1981. 


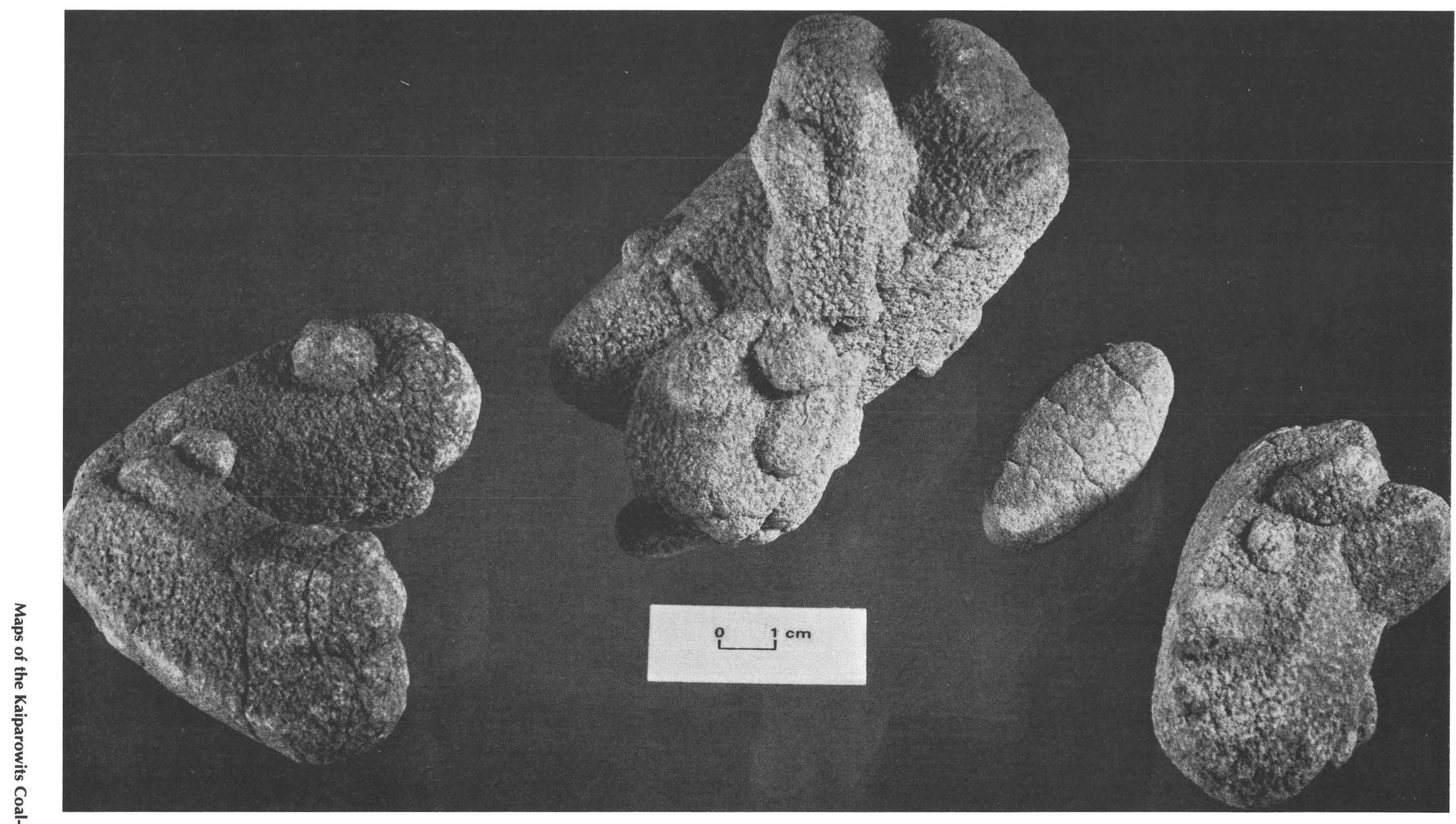

Figure 15. Sand-calcite crystals from Morrison Formation south of Escalante. Photograph by Dawn Reed, 1981. 
are shown on the map. Good specimens remain in many of the less accessible areas. Mollusks (fig. 12), sharks teeth (fig. 13), dinosaur bones, "Moqui marbles" and sand-calcite crystals (figs. 14 and 15) occur at various sites. A detailed report of sand crystals from a small locality south of Escalante has been prepared by Sargent and Zeller (in press). These crystals are the first reported occurrence from rocks of Jurassic age and the only reported sand crystals in southern Utah. Colorful red and yellow agates, probably formed by silicification of tuffaceous sediment under the basaltic cap of the Aquarius Plateau, are relatively abundant and can be found in numerous places around the Aquarius Plateau and south of the plateau in pediment deposits. Towering rock columns, demoiselles, and deep canyons a few feet wide and hundreds of feet deep (fig. 16), add to a hiker's interest and the enchantment of the slickrock country. The canyon lands are full of beautiful natural bridges, windows, and arches. Many are well known locally, such as Peek-a-boo Rock, Wahweap Window, and Jacob Hamblin Arch. Others are

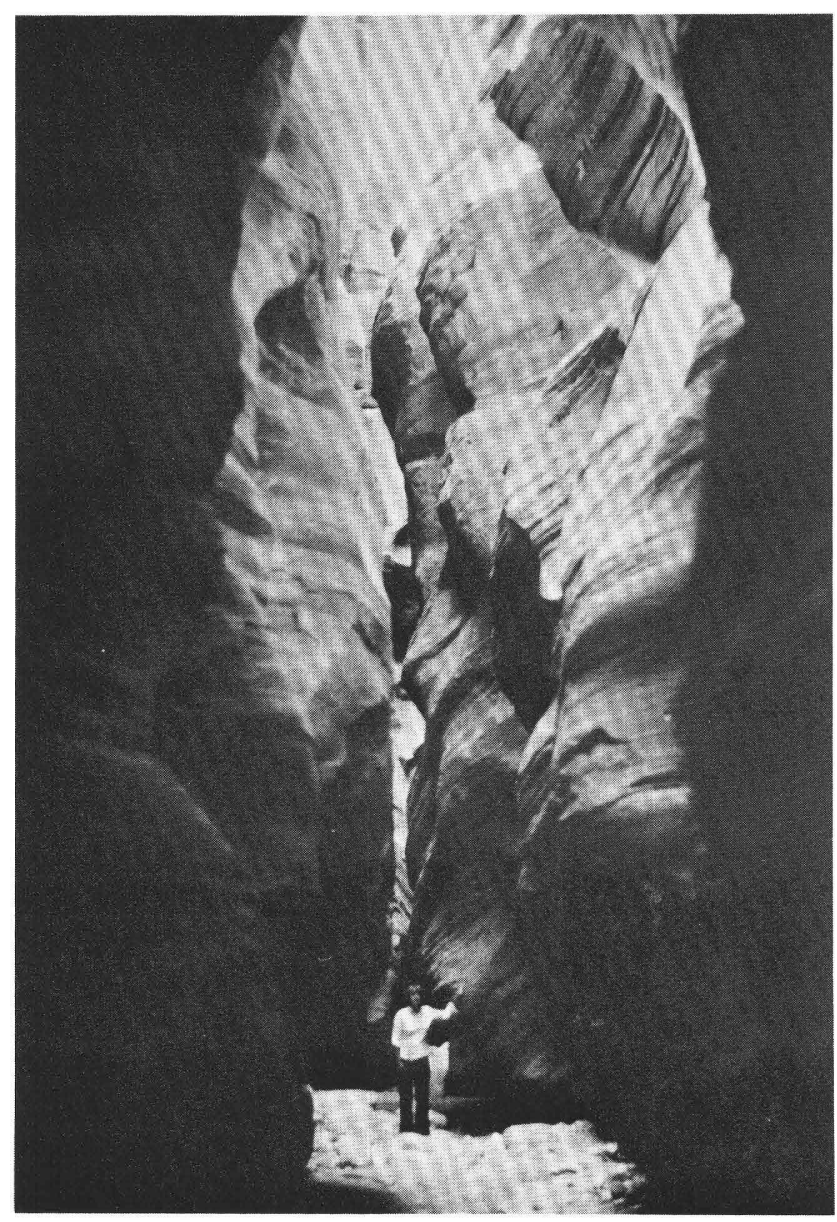

Figure 16. Narrow canyon cut in Navajo Sandstone, Kaibab Gulch. Canyon bottoms offer cool relief from the summer sun, but are extremely dangerous during flash floods. Photograph by B. C. Philpott, 1978.

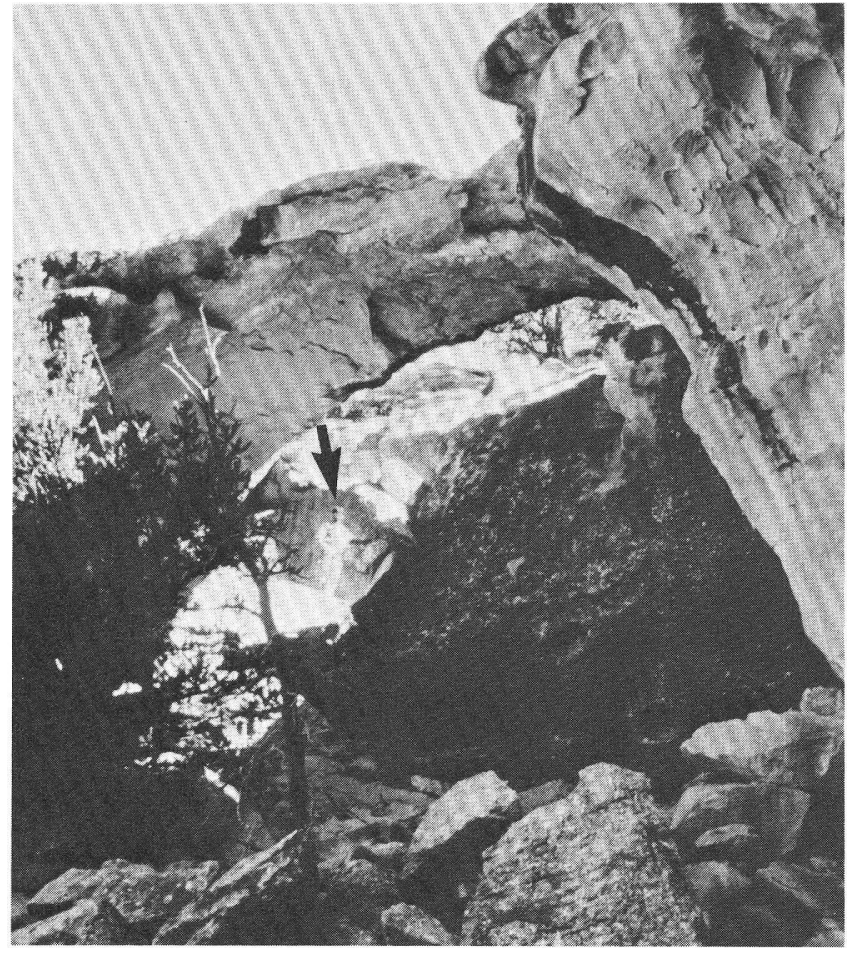

Figure 17. Unnamed natural bridge near junction of Alvey Wash and Calf Canyon, southwest of Escalante. Man (arrow) gives scale. Photograph by K. A. Sargent, 1979.

seldom visited, such as Starlight, Cobra, Sam Pollack, Woolsey, and Lamanite Arches, and several more that are unnamed (fig. 17). Many of these features are remote and can be reached on foot only; they make an attractive destination for hikers and explorers. The discussion concludes with a brief historical sketch of early settlement and short descriptions of coal, oil, and uranium exploration in the area.

\section{Surficial Geologic Map}

This map (Williams, 1984) provides information about geologic materials and processes that occur at or near the ground surface. It locates and describes 48 different types of surficial geologic material that may have practical uses or may impose limitations on the use of certain areas. It also describes the geomorphic processes that affect different parts of the area and may of themselves impose limitations on use of the land.

The map is intended to aid in planning and feasibility assessment of projects where availability of natural construction materials, excavation and foundation conditions, slope stability, and geologic hazards must be considered.

Surficial materials, which extend from $1 \mathrm{~m}$ to more than $100 \mathrm{~m}$ below the ground surface, are subdivided on 
the basis of genesis, lithologic composition, and age. The major genetic divisions are: alluvium, colluvium, eolium, residuum, and bedrock. These categories are further subdivided according to specific genesis. For example, alluvial deposits are classified as flood-plain alluvium, terrace alluvium, fan alluvium, pediment alluvium, or sheetwash alluvium. The materials subdivision for deposits is based primarily on lithology generalized as sandstone, quartzite, limestone, volcanic rock, and fine-textured sediment (lacking clasts). Bedrock outcrop material is subdivided according to rock type rather than by formations. Rock types are generalized as: shale, interbedded sandstone and shale, massive sandstone, quartzite-cobble conglomerate, limestone, volcanic rock, and baked rock (by burning coal). Some of the deposits are further subdivided by grouping into three general age ranges: Holocene, late Pleistocene, and late Pleistocene to late Pliocene(?).

\section{THE USE OF MAPS IN COMBINATION}

The favorability of certain land uses can be evaluated by combining all or parts of the maps previously discussed. The simplified examples presented here are supported by generalized versions of the maps.

\section{Coal Mining Areas}

Hansen's two maps showing coal extent and thickness (1978a) and amount of overburden (1978b) can be combined to provide a guide to planning the location of mines. Where the area of thickest coal (fig. 18) is superimposed with an overlay of thickness of overburden, an area of relative favorability for coal mining is defined. More specifically, the area where overburden exceeds $1,000 \mathrm{ft}$ is excluded as unfavorable and the remaining area of thick coal where overburden is less than 1,000 $\mathrm{ft}$ is defined (fig. 19). Additionally, if the area of roughest terrain (from Sargent and Hansen, 1980) is superimposed (fig. 20), the still-remaining areas should be even more favorable for siting coal-mine shafts.

Nine mining sites have, in fact, been proposed, all of which are within the area outlined above as favorable. Figure 21 shows the area of the current coal leasing and the proposed location of the El Paso Red and Blue coal mines and the Mono Power Company, et al. 1 to 5 mines (U.S. Department of the Interior, 1979) in southern Kaiparowits coal-basin area. Most of the mines and leases are well placed with respect to the criteria of thick coal, thin overburden, and smooth terrain. Two mines, the Blue Mine and Kaiparowits No. 5, are on either side-hill or valley-bottom locations that would add to construction costs and be susceptible to erosion and (or) mudslides during or after heavy rainstorms.

\section{Transportation Routes}

Coal haulage roads, electrical transmission lines, and access roads should be routed with consideration of geology, landforms and topography, landslide and rockfall susceptibility, and effect on scenic value. The usefulness of the maps in this folio for road and transmission line location can be illustrated by examples from the area of current coal mining interest in the southern Kaiparowits Plateau. Lease areas there are separated from the nearest paved highway (U.S. 89) by extensive rugged terrain (Sargent and Hansen, 1980). Existing roads (fig. 22) are poor; major road construction and realinement will be a necessary first step if development occurs. Smoky Mountain Road (fig. 22), if used, would have to be upgraded to accommodate heavy truck traffic. The existing Missing Canyon Road (fig. 22) follows the stream bottom from the southwest side of Smoky Mountain to its intersection with the Warm Creek Road; both road segments have potential problems in maintenance and construction-the Missing Canyon and Kelly Grade section of Smoky Mountain Road have potential landslide and rockfall hazards (Fuller and others, 1981), shaly horizons in the Straight Cliffs Formation may cause road stability problems, and Missing Canyon Road is susceptible to washouts where branches of Warm Creek cross it. Warm Creek Road is constructed throughout its length on the clay-rich Tropic Shale (Sargent and Hansen, 1982), a rock unit notorious for its lack of stability on slopes or when wet. An alternate access road (proposed in the 1979 EIS, Part 2, p. RB-II-9) down Nipple Creek appears to be more favorable than the other routes. It crosses less of the unstable rock, does not have such a high potential for washout, and does not cross any of the Glen Canyon National Recreation Area. None of the routes appear to endanger areas of high scenic value (Carter and Sargent, 1983). Gravels from Wahweap Creek or the pediment gravels on Horse Mountain (fig. 3) would be good sources for road aggregate (U.S. Bureau of Land Management, 1976; Williams, 1984).

\section{Townsites}

Any major development of the coal resources of the Kaiparowits coal-basin area would require establishing at least one new town and would also result in some growth in existing towns. Careful planning for this growth in population would be necessary, and consideration of the geologic and hydrologic conditions at a given site would be essential for successful planning. Two examples, a proposed new townsite on East Clark Bench (fig. 22) and the existing town of Escalante (fig. 22), illustrate this need.

The 1976 Environmental Impact Statement (U.S. 


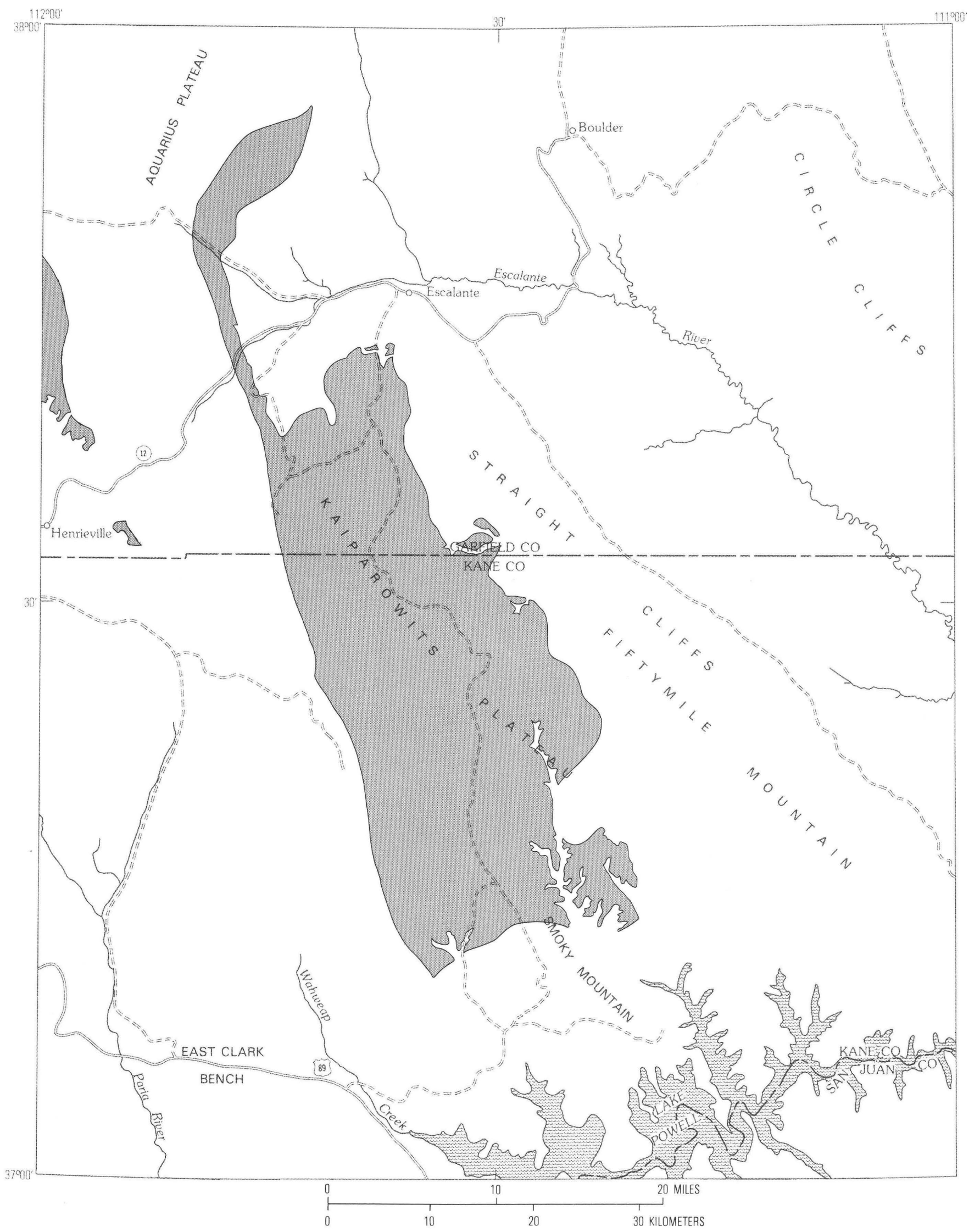

Figure 18. Generalized area of thickest coal ( $>8 \mathrm{ft}$ ). Modified from Hansen (1978a). 


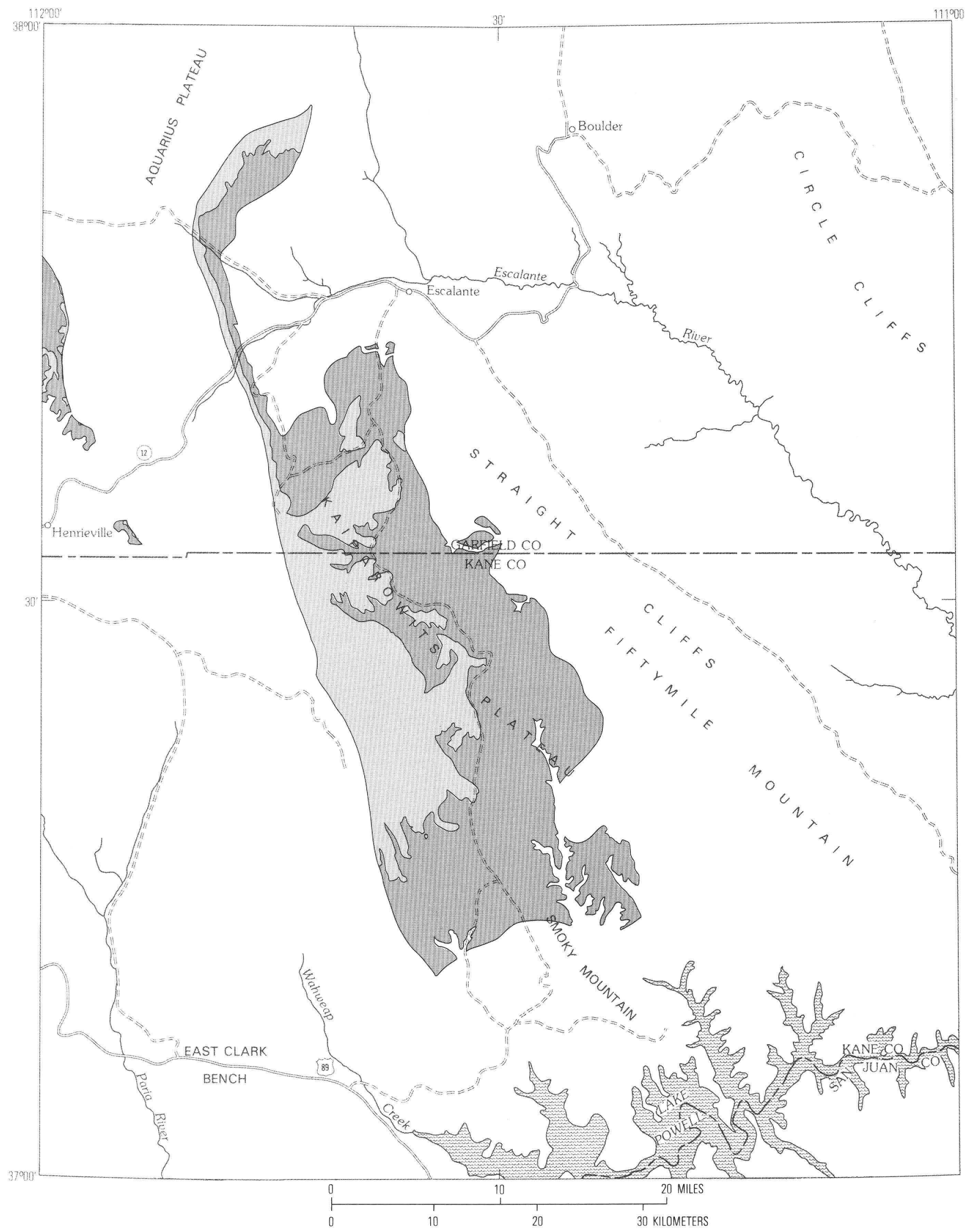

Figure 19. Generalized area of thickest coal showing where overburden is less than 1,000 ft thick (dark stipple), and where overburden is greater than 1,000 ft (light stipple). Modified from Hansen (1978a, b). 


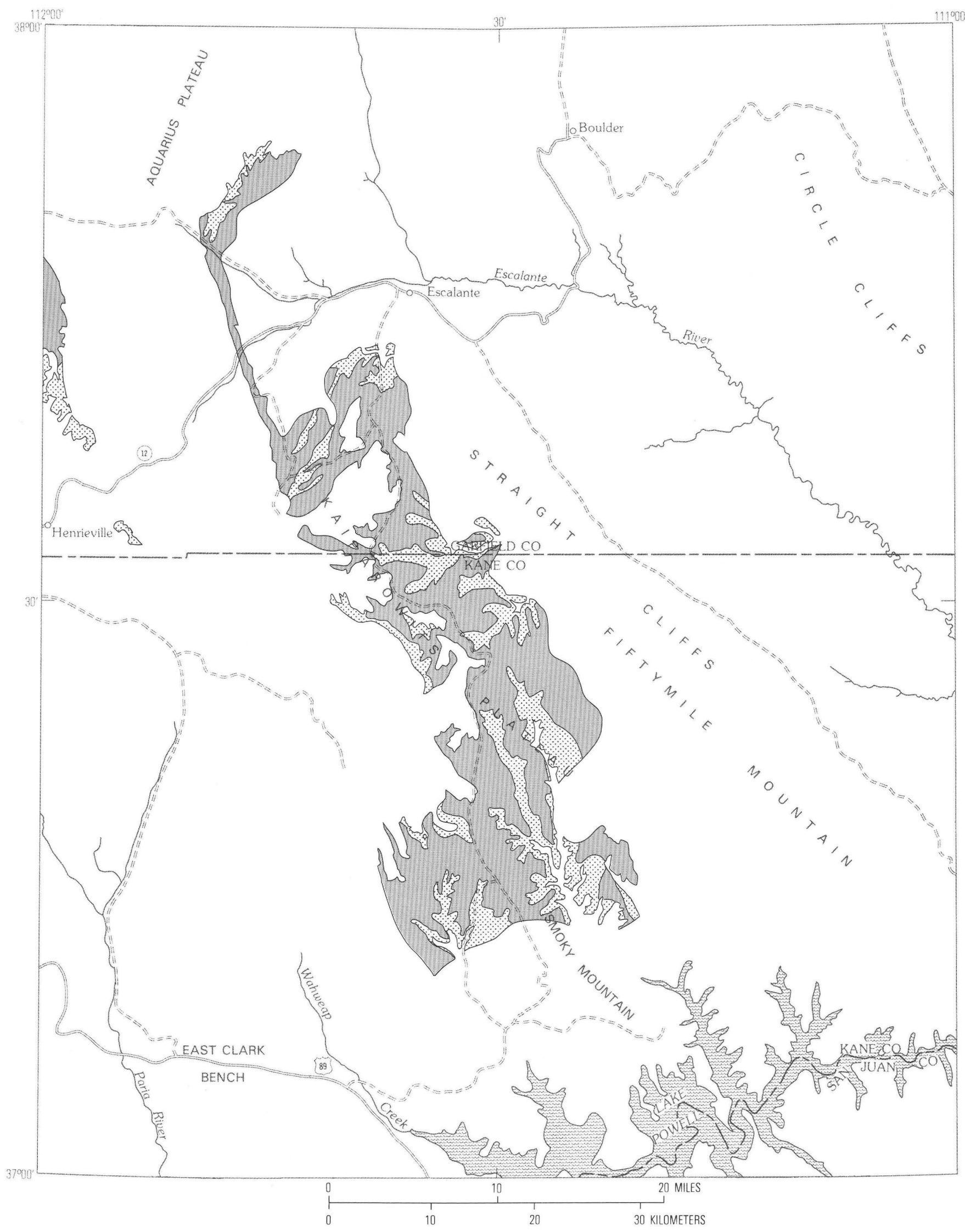

Figure 20. Generalized map of area of thickest coal where overburden is less than 1,000 feet thick showing areas of roughest terrain (patterned). Modified from Hansen (1978a, b) and Sargent and Hansen (1980). 


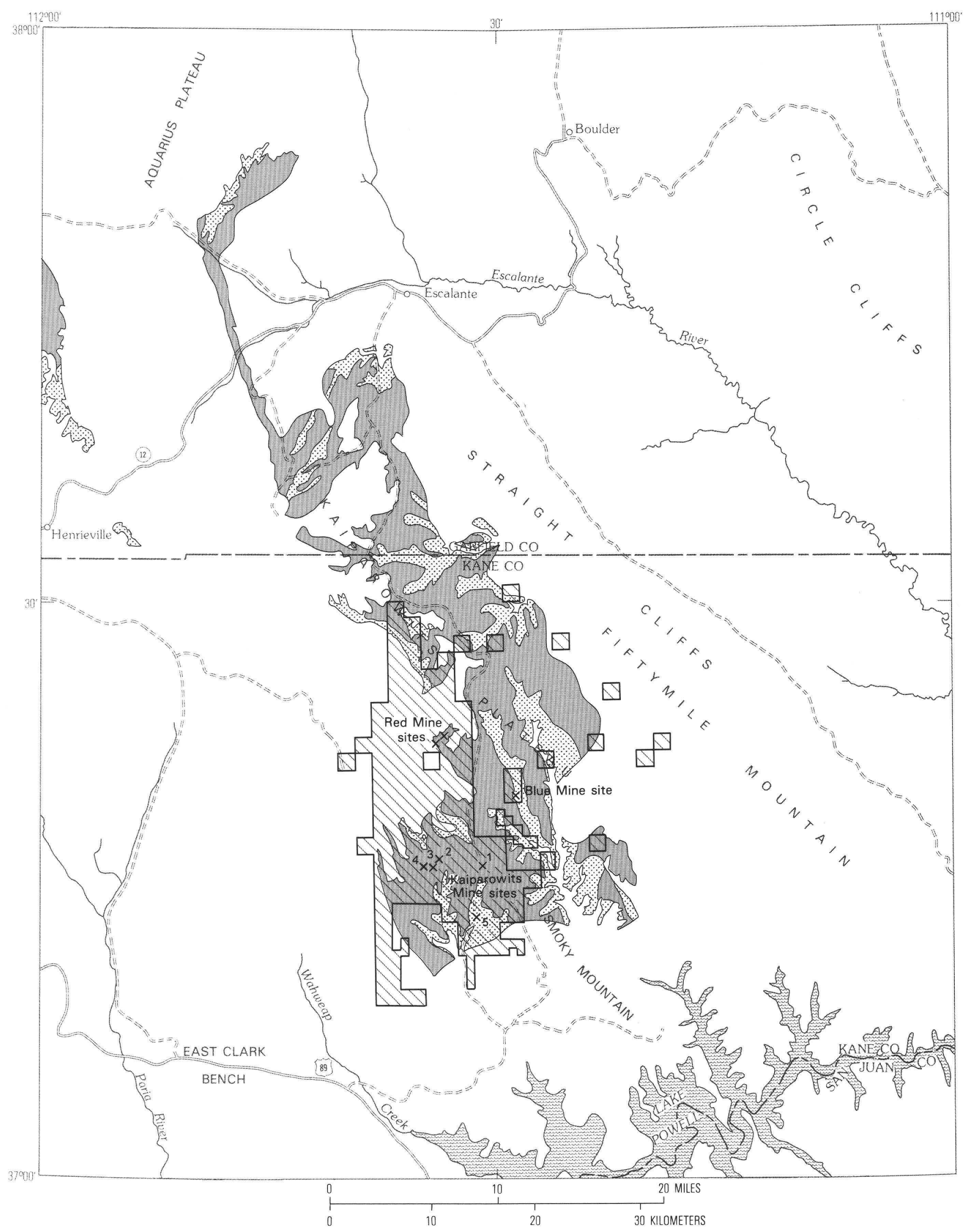

Figure 21. Generalized map showing areas of present coal leases (cross hatched) and proposed mining sites ( $x$ ) in relation to thickest coal and least amount of overburden (dark stipple), and areas of roughest terrain (patterned) (factors considered in figs. 18, 19, and 20). 


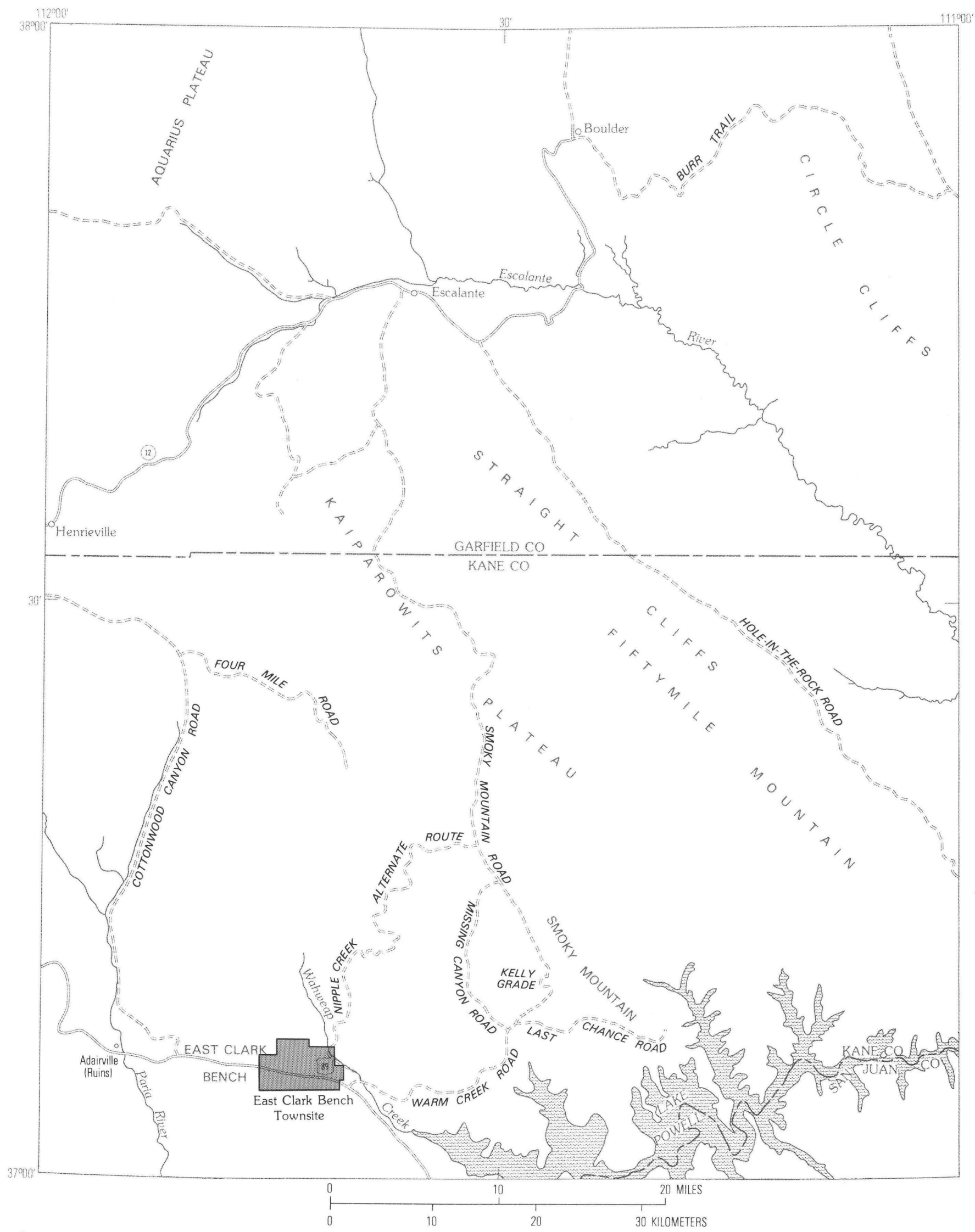

Figure 22. Kaiparowits coal-basin area showing some existing unimproved roads and the proposed townsite at East Clark Bench. 
Bureau of Land Management, 1976) discussed a preferred new townsite on East Clark Bench. This site was preferred because of accessibility (U.S. Highway 89 passes close by), sufficient space for residential, commercial, and industrial development, favorable climate, and proximity to the proposed mines (25 mi distant) and Lake Powell recreation area (about $20 \mathrm{mi}$ distant).

Water needs for the East Clark Bench townsite were estimated at about 5,000,000 gal/day $(9,690 \mathrm{acre} \mathrm{ft} / \mathrm{yr})$. The preferred source for the water was six wells, all less than 2,000 $\mathrm{ft}$ deep, drilled into the Navajo Sandstone. Each well was estimated to be able to give a sustained yield of about $1,000 \mathrm{gal} / \mathrm{min}$. A contingency source of water for the town was to be from the 102,000 acre $\mathrm{ft}$ of water allocated from Lake Powell for the proposed power project. The Paria River to the west near Adairville (fig. 22) and Wahweap Creek to the north could supply a limited amount of poor-quality water for agricultural purposes. Treated sewage water could also be used for agricultural purposes. No other sources of water adequate for a town of the size proposed are available.

The East Clark Bench townsite has many inadequacies. It lacks a soil-stabilizing vegetative cover and has only a thin to almost nonexistent layer of poor soil in which to establish a vegetative cover. Much of the site area is dense sandstone and shale covered with a few feet of eolian sand. The shallow depth to bedrock would considerably increase the construction cost of basements and pipelines. The windblown sand cover is unstable and could cause considerable damage to vegetation and property during windstorms. Treated effluent from the sewage plant, possibly as much as $5,000,000 \mathrm{gal} / \mathrm{day}$, would run off into Lake Powell. This effluent, even though treated, would have a high dissolved solid content which, although it would be a very minor amount relative to natural inflow, would be undesirable.

The East Clark Bench townsite does not appear to endanger any areas of great scenic value (Carter and Sargent, 1983).

Escalante is a town of about 650 people situated on the Escalante River near the north end of the Straight Cliffs (fig. 22). It is the largest town in the Kaiparowits coal-basin area, and any large-scale development of the coal resources would cause the town to grow considerably.

The domestic water supply for Escalante is from several springs and small reservoirs in the Aquarius Plateau area (fig. 22), and agricultural water for the area is supplied by Wide Hollow Reservoir (fig. 3) just west of the town. Any large population growth would necessitate finding additional sources of water. Alternative means of increasing the public water supply are to increase reservoir storage capacities or drill deep wells. Several possible nearby well locations seem favorable. Wells sited by an experienced ground-water hydrologist and drilled no deeper than 3,000 ft into the Entrada Sandstone of Jurassic age or the Navajo Sandstone of Triassic(?) and Jurassic age, along the Alvey Wash syncline (fig. 4) or the Bailey Wash syncline (fig. 4), could yield as much as 1,000 $\mathrm{gal} / \mathrm{min}$ of high-quality water on a sustained basis. (See Price, 1977a, b; Goode, 1969; Lidke and Sargent, 1983, for hydrologic and geologic data.)

During 1977, the Escalante area experienced a severe drought; Wide Hollow Reservoir was extremely low, and the springs and creeks that supply the town's culinary water were going dry. This seems to indicate the desirability of having a contingency water supply-presumably from deep wells.

The present limits of the Escalante townsite could absorb some population growth, but any growth beyond the present town limits would have to be carefully planned. Valley fill (alluvium), normally considered ideal for commercial and residential growth, is the best and most arable soil in the area and should be considered for retention as farm land. Some of the areas of valley fill, the bottomlands, or flood plains, are subject to flooding and should be carefully evaluated before being designated for human habitation. Areas west of Escalante seemingly available for townsite expansion are underlain by the Tropic Shale, a formation with a high content of expanding clay and poorly suited for road and foundation construction. Areas close to the Escalante Rim (northern Straight Cliffs) are susceptible to landsliding (Fuller and others, 1981).

\section{Oil Exploration}

The bedrock geologic map (Sargent and Hansen, 1982) and cross sections (Lidke and Sargent, 1983) may form a basis for planning additional oil exploration programs in the Kaiparowits area. Oil exploration to 1981 is summarized here along with an evaluation of the structures that might have further potential for oil production.

Oil exploration began in the Kaiparowits area in 1921 when the Ohio Oil Company drilled a 3,212-ft dry hole on the Circle Cliffs anticline. Eighteen dry holes were drilled in the area before Tenneco made a discovery in the Upper Valley field in 1964. This field has a total of 28 wells that have produced from the TimpoweapKaibab interval (Triassic Timpoweap Member of the Moenkopi Formation, and Permian Kaibab Limestone). Other wells drilled in the Kaiparowits area to test hydrocarbon accumulation in the Timpoweap-Kaibab interval are shown on figure 23. It appears that only the Smoky Mountain anticline (SM) and the Cedar Mountain anticline $(\mathrm{CM})$, in their southern extensions, have any potential for petroleum production in the Timpoweap-Kaibab.

Deeper formations with potential for hydrocarbon accumulation include the White Rim Sandstone Member 


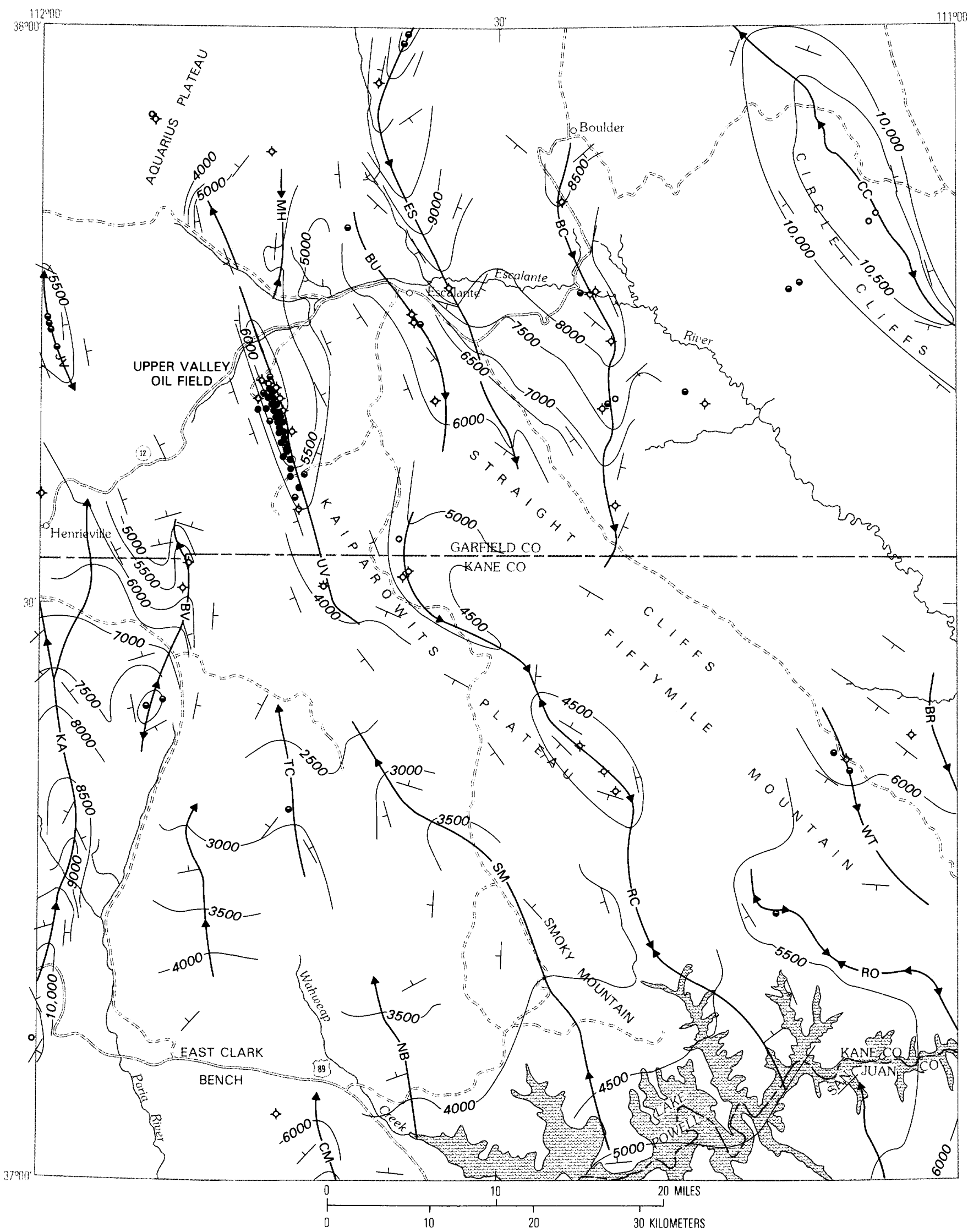

Figure 23. Map showing all deep drill holes in Kaiparowits Plateau area and showing data on Timpoweap-Kaibab interval. Structure contours modified from Hackman and Wyant (1973). 


\section{EXPLANATION}

\begin{tabular}{|c|c|}
\hline$-6000-$ & $\begin{array}{l}\text { PARTIAL STRUCTURE CONTOURS ON DAKOTA SAND- } \\
\text { STONE-Projected in part, contour interval } 500 \mathrm{ft}\end{array}$ \\
\hline & AXIS OF ANTICLINE-Showing plunge \\
\hline & NAMED ANTICLINES \\
\hline$B C$ & Boulder-Collet Canyon \\
\hline BR & Bridge \\
\hline BU & Button \\
\hline BV & Butler Valley \\
\hline $\mathrm{CC}$ & Circle Cliffs \\
\hline $\mathrm{CM}$ & Cedar Mountain \\
\hline ES & Escalante \\
\hline JV & Johns Valley \\
\hline KA & Kaibab \\
\hline $\mathrm{MH}$ & Moquil Hut \\
\hline NB & Nipple Bench \\
\hline $\mathrm{RC}$ & Rees Canyon \\
\hline RO & Rock Creek \\
\hline SM & Smoky Mountain \\
\hline $\mathrm{TC}$ & Tommy Canyon \\
\hline UV & Upper Valley \\
\hline WT & Willow Tank \\
\hline
\end{tabular}

1 STRIKE AND DIRECTION OF DIP OF BEDS AT SURFACE

- $\quad$ PRODUCING WELL-Timpoweap-Kaibab interval

- WELL WITH SHOW OF OIL-Timpoweap-Kaibab' interval

* WELL WITH SHOW OF GAS-Timpoweap-Kaibab interval

\&. WELL WITH NO SHOWS OF GAS OR OIL-Timpoweap-Kaibab interval WELL SPUDDED BELOW TIMPOWEAP-KAIBAB INTERVALNo information available, or not drilled deep enough to encounter Timpoweap-Kaibab interval

of the Cutler Formation (Permian), Organ Rock Tongue of the Cutler Formation (Permian), Cedar Mesa Sandstone Member of the Cutler Formation (Permian), Toroweap Formation (Permian), Hermosa and Molas Formations (Pennsylvanian), Redwall Limestone (Mississippian), and Tapeats Sandstone (Cambrian). Many of these units have been penetrated on several anticlines in the area, and a few holes have encountered good shows of oil and gas (fig. 24). The types of shows and the formations where they occur are given where information is available. The Upper Valley anticline is the only structure that has had production below the Timpoweap-Kaibab interval. Here, the Redwall Limestone produced 16,431 barrels of oil of $17.2^{\circ}$ gravity from the California Company Upper Valley No. 1 well (Kunkel, 1965). The oil was recovered, however, only after extensive swabbing and pumping. Most of the larger structures have been penetrated and appear to have shows in at least one of the deeper intervals. Two unexplored structures in the Kaiparowits area are the
Smoky Mountain anticline (SM) and the Circle Cliffs anticline (CC) north of the Hunt No. 1 Circle Cliffs well (drill hole 9 on fig. 24), where closure has been suggested by Steed (1954).

\section{SUMMARY AND CONCLUSIONS}

The U.S. Geological Survey Energy Lands Program for the Kaiparowits coal-basin area of south-central Utah consists of 12 geologic and hydrologic maps summarizing the latest earth-science data. This report briefly discusses the content and use of each of these maps and how they may help developers and land-use planners make effective decisions where earth science is involved.

It is unlikely that the vast coal resources of the Kaiparowits Plateau will long remain undeveloped, but it seems likely that development will be constrained by strict standards to prevent unnecessary or excessive degradation of the environment. Difficult decisions will be necessary in the face of conflicting interests. It is hoped that the body of objective data encompassed in this study will facilitate the best possible decisions and the most intelligent compromises between conflicting national needs.

\section{REFERENCES CITED}

Averitt, Paul, and Cashion, W. B., 1965, History of coal production in southwestern Utah, in Geology and resources of south central Utah-Resources for power: Utah Geological Society Guidebook to Geology of Utah 19, p. 113-120.

Bowers, W. E., 1972, The Canaan Peak, Pine Hollow, and Wasatch Formations in the Table Cliff region, Garfield County, Utah: U.S. Geological Survey Bulletin 1331-B, $39 \mathrm{p}$.

1973a, Geologic map and coal resources of the Upper Valley quadrangle, Garfield County, Utah: U.S. Geological Survey Coal Investigations Map C-60, scale 1:24,000.

1973b, Geologic map and coal resources of the Griffin Point quadrangle, Garfield County, Utah: U.S. Geological Survey Coal Investigations Map C-61, scale 1:24,000.

-1973c, Geologic map and coal resources of the Pine Lake quadrangle, Garfield County, Utah: U.S. Geological Survey Coal Investigations Map C-66, scale 1:24,000.

-1975 , Geologic map and coal resources of the Henrieville quadrangle, Garfield and Kane Counties, Utah: U.S. Geological Survey Coal Investigations Map C-74, scale $1: 24,000$.

Carter, L. M. H., and Sargent, K. A., 1983 (1984), Scenic features related to geology in the Kaiparowits Plateau area, Utah: U.S. Geological Survey Miscellaneous Investigations Map I-1033-K, scale 1:125,000.

Davidson, E. S., 1967, Geology of the Circle Cliffs area, Garfield and Kane Counties, Utah: U.S. Geological Survey Bulletin $1229,140 \mathrm{p}$. 


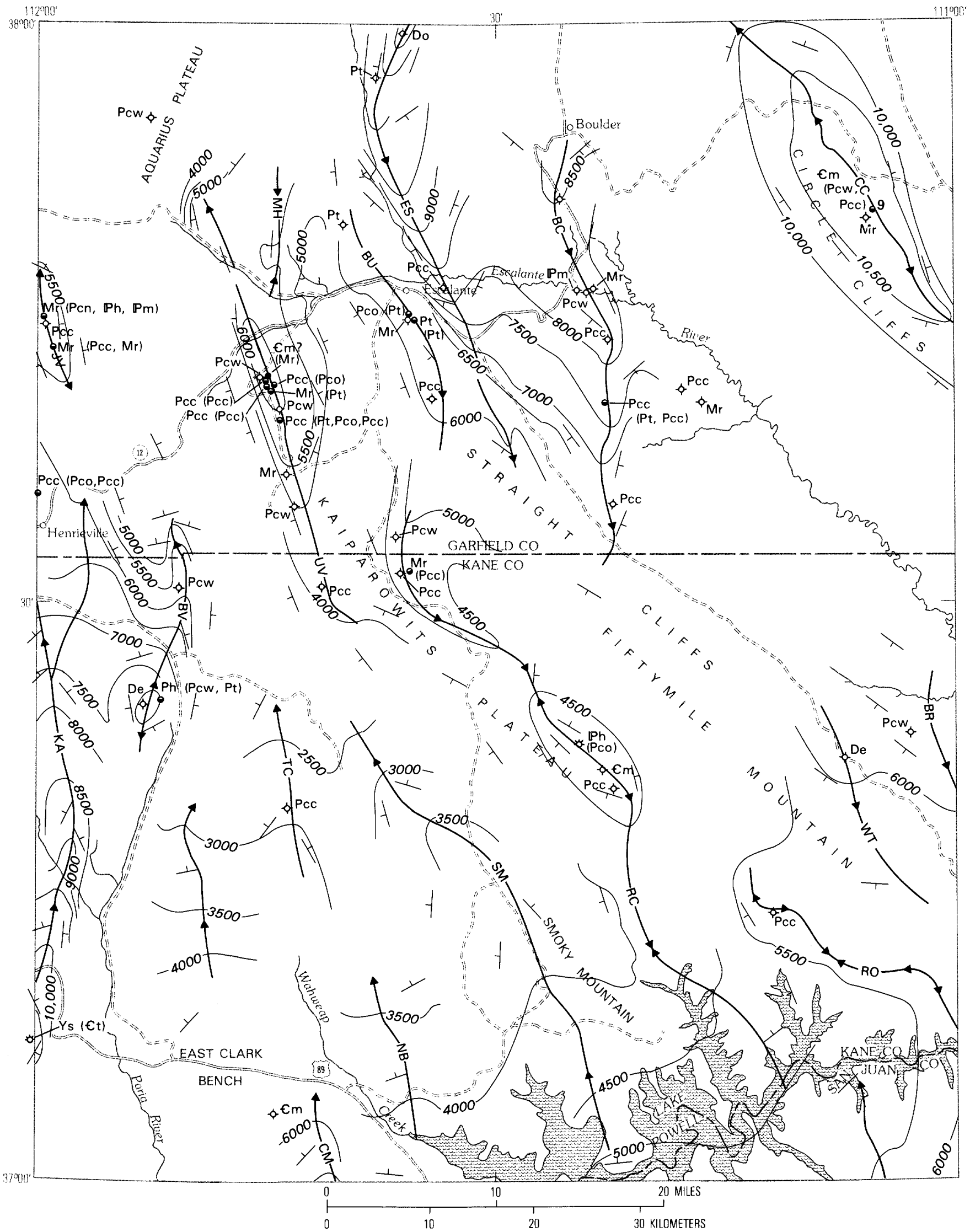

Figure 24. Map showing exploratory holes in Kaiparowits Plateau area drilled deeper than Timpoweap-Kaibab interval. Structure contours modified from Hackman and Wyant (1973). Drill hole 9 mentioned in text. 


\section{EXPLANATION}

\begin{tabular}{|c|c|}
\hline$-6000-$ & $\begin{array}{l}\text { PARTIAL STRUCTURE CONTOURS ON DAKOTA SAND- } \\
\text { STONE-Projected in part, contour interval } 500 \mathrm{ft}\end{array}$ \\
\hline & AXIS OF ANTICLINE-Showing plunge \\
\hline & NAMED ANTICLINES \\
\hline $\mathrm{BC}$ & Boulder-Collet Canyon \\
\hline BR & Bridge \\
\hline BU & Button \\
\hline BV & Butler Valley \\
\hline $\mathrm{CC}$ & Circle Cliffs \\
\hline $\mathrm{CM}$ & Cedar Mountain \\
\hline ES & Escalante \\
\hline JV & Johns Valley \\
\hline KA & Kaibab \\
\hline $\mathrm{MH}$ & Moqui Hut \\
\hline NB & Nipple Bench \\
\hline $\mathrm{RC}$ & Rees Canyon \\
\hline RO & Rock Creek \\
\hline & Smoky Mountain \\
\hline & Tommy Canyon \\
\hline & Upper Valley \\
\hline WT & Willow Tank \\
\hline 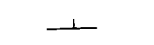 & STRIKE AND DIRECTION OF DIP OF BEDS AT SURFACE \\
\hline$\stackrel{\left.E_{m} r\right)}{(M r)}$ & $\begin{array}{l}\text { PRODUCING WELLL-Showing deepest interval penetrated, and } \\
\text { (in parentheses) producing horizon: queried where uncertain }\end{array}$ \\
\hline$\bullet_{(\mathrm{Pcc})}^{\mathrm{Pcc}}$ & $\begin{array}{l}\text { WELL WITH SHOW OF OIL-Showing deepest interval } \\
\text { penetrated, and (in parentheses) interval with show }\end{array}$ \\
\hline$* \underset{(P \operatorname{Ph})}{\mathbb{P h}}$ & $\begin{array}{l}\text { WELL WITH SHOW OF GAS-Showing deepest interval } \\
\text { penetrated, and (in parentheses) interval with show }\end{array}$ \\
\hline$\Leftrightarrow \mathrm{Pcc}$ & NO SHOWS REPORTED-Showing deepest interval penetrated \\
\hline & PERMIAN \\
\hline $\mathrm{Pt}$ & Toroweap Formation \\
\hline Pcu & Coconino Sandstone \\
\hline Pcw & White Rim Sandstone Member of Cutler Formation \\
\hline Pco & Organ Rock Tongue of Cutler Formation \\
\hline Pcc & Cedar Mesa Sandstone Member of Cutler Formation \\
\hline $\mathrm{Ph}$ & Hermit Shale \\
\hline & PENNSYLVANIAN \\
\hline $\mathbb{P h}$ & Hermosa Formation \\
\hline $\mathbb{P m}$ & Molas Formation \\
\hline & MISSISSIPPIAN \\
\hline & Redwall Limestone \\
\hline & DEVONIAN \\
\hline Do & Ouray Limestone \\
\hline $\mathrm{De}$ & Elbert Formation \\
\hline & CAMBRIAN \\
\hline$\epsilon_{m}$ & Muav Limestone \\
\hline$\epsilon_{\mathrm{t}}$ & Tapeats Sandstone \\
\hline & MIDDLE PROTEROZOIC \\
\hline Ys & Shinumo Quartzite \\
\hline
\end{tabular}

Doelling, H. H., and Graham, R. L., 1972, Southwestern Utah coal fields-Alton, Kaiparowits Plateau and Kolob-Harmony: Utah Geological and Mineralogical Survey Monograph Series No. 1, $333 \mathrm{p}$.

Fenneman, N. M., 1931, Physiography of western United States: New York, McGraw-Hill, 534 p.
Fuller, H. K., Williams, V. S., and Colton, R. B., 1981, Areas of landslides and potential landsliding in the Kaiparowits coal-basin area, Utah: U.S. Geological Survey Miscellaneous Investigations Map I-1033-H, scale 1:125,000.

Goode, H. D., 1969, Reconnaissance appraisal of the water resources near Escalante, Garfield County, Utah: Utah Geological and Mineral Survey Water-Resources Bulletin $11,38 \mathrm{p}$.

Gregory, H. E., 1948, Geology and geography of central Kane County, Utah: Geological Society of America Bulletin, v. 59 , no. 3 , p. $211-248$.

Gregory, H. E., and Moore, R. C., 1931, The Kaiparowits region, a geographic and geologic reconnaissance of parts of Utah and Arizona: U.S. Geological Survey Professional Paper 164, $161 \mathrm{p}$.

Hansen, D. E., 1978a, Map showing extent and total thickness of coal beds in the Kaiparowits coal basin, Utah: U.S. Geological Survey Miscellaneous Investigations Map I1033-C, scale 1:125,000.

-1978b, Maps showing amount of overburden on major coal zones in the Kaiparowits coal basin, Utah: U.S. Geological Survey Miscellaneous Investigations Map I1033-D, scale 1:125,000.

Hackman, R. J., and Wyant, D. G., 1973, Geology, structure, and uranium deposits of the Escalante quadrangle, Utah and Arizona: U.S. Geological Survey Miscellaneous Geologic Investigations Map I-744, scale 1:250,000.

Hem, J. D., 1970, Study and interpretation of the chemical characteristics of natural water (2nd ed.): U.S. Geological Survey Water-Supply Paper 1473, 303 p.

Hintze, L. F., 1963, Geologic map of southwestern Utah: Washington, D.C., Williams and Heintz Map Corporation, available from Utah Geological and Mineral Survey, Salt Lake City, Utah 84112, scale 1:250,000.

Hintze, L. F., and Stokes, W. L., 1964, Geology map of southeastern Utah: Washington, D.C., Williams and Heintz Map Corporation, available from Utah Geological and Mineral Survey, Salt Lake City, Utah 84112, scale 1:250,000.

Kunkel, R. P., 1965, History of exploration for oil and natural gas in the Kaiparowits region, Utah, in Geology and resources of south-central Utah-Resources for power: Utah Geological Society Guidebook to Geology of Utah 19, p. 93-111.

Lidke, D. J., and Sargent, K. A., 1983, Geologic cross sections of the Kaiparowits coal-basin area, Utah: U.S. Geological Survey Miscellaneous Investigations Map I-1033-J, scale $1: 125,000$.

Peterson, Fred, 1969, Four new members of the Upper Cretaceous Straight Cliffs Formation in the southeastern Kaiparowits region, Kane County, Utah: U.S. Geological Survey Bulletin 1274-J, p. 1-28.

1973 (1974), Geologic map of the southwest quarter of the Gunsight Butte quadrangle, Kane and San Juan Counties, Utah, and Coconino County, Arizona: U.S. Geological Survey Mineral Investigations Field Study Map MF-306, scale $1: 24,000$.

1975, Geologic map of the Sooner Bench quadrangle, Kane County, Utah: U.S. Geological Survey Miscellaneous Geologic Investigations Map I-874, scale 1:24,000. 
Peterson, Fred, and Barnum, B. E., 1973a, Geologic map of the southeast quarter of the Cummings Mesa quadrangle, Kane and San Juan Counties, Utah and Coconino County, Arizona: U.S. Geological Survey Miscellaneous Geologic Investigations Map I-758, scale 1:24,000.

1973b, Geologic map of the southwest quarter of the Cummings Mesa quadrangle, Kane and San Juan Counties, Utah, and Coconino County, Arizona: U.S. Geological Survey Miscellaneous Geologic Investigations Map I-759, scale 1:24,000.

$1973 \mathrm{c}$, Geologic map and coal resources of the northeast quarter of the Cummings Mesa quadrangle, Kane County, Utah: U.S. Geological Survey Coal Investigations Map C63 , scale $1: 24,000$.

1973d, Geologic map and coal resources of the northwest quarter of the Cummings Mesa quadrangle, Kane County, Utah: U.S. Geological Survey Coal Investigations Map C64 , scale $1: 24,000$.

Price, Don, 1977a, Map showing general chemical quality of ground water in the Kaiparowits coal-basin area, Utah: U.S. Geological Survey Miscellaneous Investigations Map I1033-A, scale 1:125,000.

1977b, Map showing general availability of ground water in the Kaiparowits coal-basin area, Utah: U.S. Geological Survey Miscellaneous Investigations Map I-1033-B, scale 1:125,000.

1978, Map showing principal drainage basins, principal runoff-producing areas, and selected streamflow data in the Kaiparowits coal-basin area, Utah: U.S. Geological Survey Miscellaneous Investigations Map I-1033-E, scale 1:125,000.

1979, Map showing general chemical quality of surface water in the Kaiparowits coal-basin area, Utah: U.S. Geological Survey Miscellaneous Investigations Map I1033-F, scale 1:125,000.

Sargent, K. A., and Hansen, D. E., 1976, General geology and mineral resources of the coal area of south-central Utah, with sections on Landslide Hazards by Roger B. Colton, Coal Mine Subsidence by C. Richard Dunrud, and Landscape Geochemistry by J. J. Connor: U.S. Geological Survey Open-File Report 76-811, 122 p.

1980, Landform map of the Kaiparowits coal-basin area, Utah: U.S. Geological Survey Miscellaneous Investigations Map I-1033-G, scale 1:125,000.

-1982 (1983), Bedrock geologic map of the Kaiparowits coal-basin area, Utah: U.S. Geological Survey Miscellaneous Investigations Map I-1033-I, scale 1:125,000.

Sargent, K. A., and Zeller, H. D., 1984, Sand-calcite crystals from Garfield County, Utah: U.S. Geological Survey Bulletin 1606 (in press).
Steed, R. H., 1954, Geology of Circle Cliffs anticline, in Geology of portions of the high plateaus and adjacent canyon lands, central and south-central Utah: Intermountain Association of Petroleum Geologists Annual Conference, 5th, 1954, Guidebook, p. 99-102.

Stephens, E. V., 1973, Geologic map and coal resources of the Wide Hollow Reservoir quadrangle, Garfield County, Utah: U.S. Geological Survey Coal Investigations Map C55 , scale $1: 24,000$.

U.S. Bureau of Land Management, 1976, Proposed Kaiparowits Project, Utah, Arizona, Nevada, California, final environmental impact statement: U.S. Government Printing Office, 3,514 p.

U.S. Department of the Interior, 1977, Quality of water, Colorado River basin: U.S. Department of the Interior Progress Report 8, 195 p.

1979, Final Environmental Statement-Development of coal resources in southern Utah, Part 1, Regional Analysis, Part 2, Site Specific Analysis: U.S. Department of the Interior, pt. 1, 451 p., pt. 2, 189 p.

U.S. Public Health Service, 1962, Drinking water standards: U.S. Public Health Service Publication 956, 61 p.

Williams, V. S., 1984, Surficial geologic map of the Kaiparowits coal-basin area, Utah: U.S. Geological Survey Miscellaneous Investigations Map I-1033-L, scale $1: 125,000$ (in press).

Zeller, H. D., 1973a, Geologic map and coal resources of the Carcass Canyon quadrangle, Garfield and Kane Counties, Utah: U.S. Geological Survey Coal Investigations Map C56 , scale $1: 24,000$.

1973b, Geologic map and coal and oil resources of the Canaan Creek quadrangle, Garfield County, Utah: U.S. Geological Survey Coal Investigations Map C-57, scale $1: 24,000$.

1973c, Geologic map and coal resources of the Death Ridge quadrangle, Garfield and Kane Counties, Utah: U.S. Geological Survey Coal Investigations Map C-58, scale $1: 24,000$.

1973d, Geologic map and coal resources of the Dave Canyon quadrangle, Garfield County, Utah: U.S. Geological Survey Coal Investigations Map C-59, scale 1:24,000.

1978, Geologic map and coal resources of the Collet Top quadrangle, Kane County, Utah: U.S. Geological Survey Coal Investigations Map C-80, scale 1:24,000.

Zeller, H. D., and Stephens, E. V., 1973, Geologic map and coal resources of the Seep Flat quadrangle, Garfield and Kane Counties, Utah: U.S. Geological Survey Coal Investigations Map C-65, scale 1:24,000. 




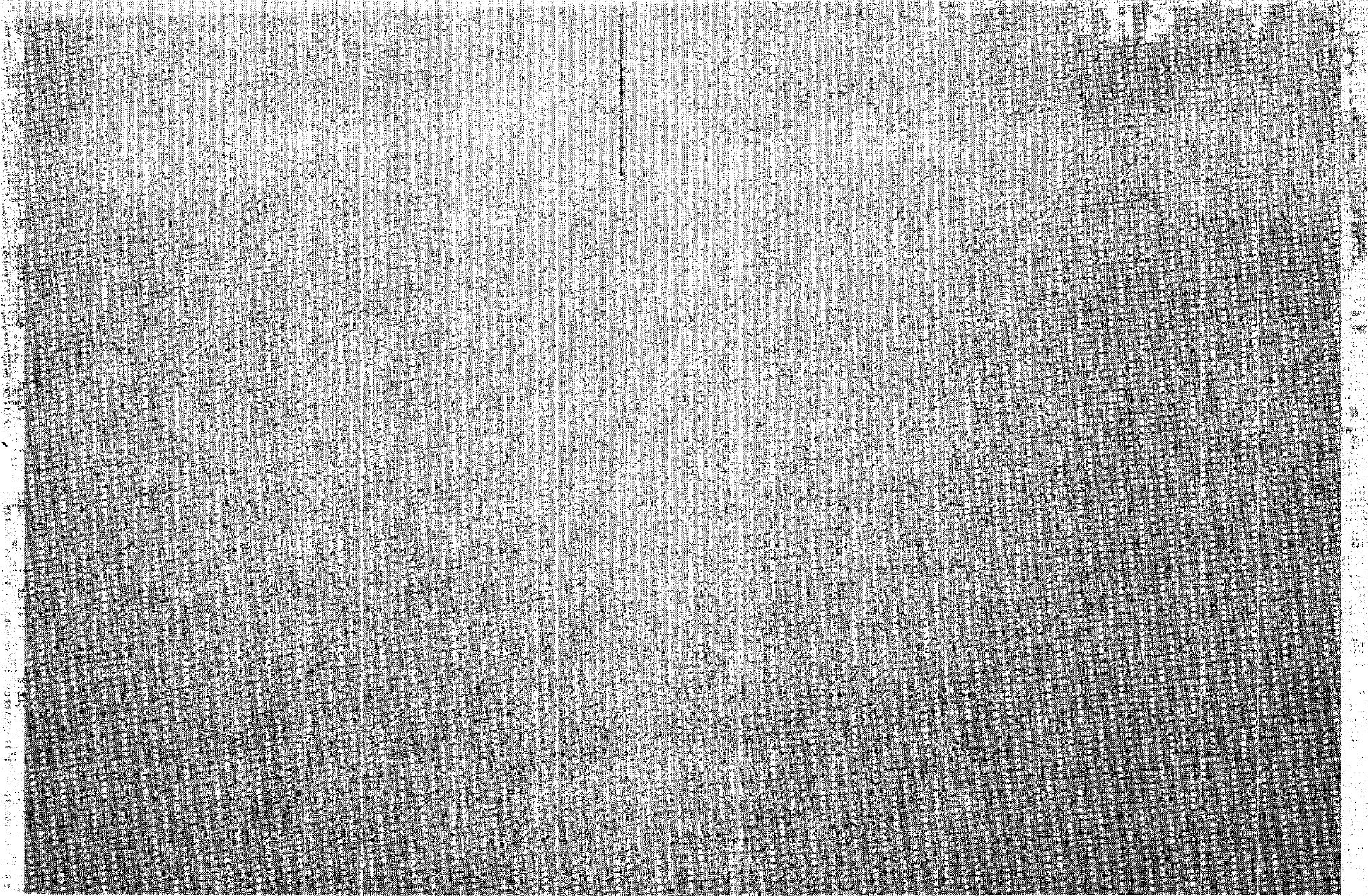

